\title{
Making continental crust: origin of Devonian orthogneisses from SE Mongolian Altai
}

\author{
Pavel HANŽL ${ }^{1 *}$, Karel SCHULMANN ${ }^{1,2}$, Vojtěch JANOUŠEK ${ }^{1,3}$, Ondrej LEXA ${ }^{3,1}$, \\ Kristýna HRDLIČKOVÁ1, Yingde JIANG ${ }^{3,6}$, David BURIÁNEK', Battushig ALTANBAATAR ${ }^{4}$, \\ Turbat GANCHULUUN ${ }^{5}$, Vojtěch ERBAN ${ }^{1}$
}

${ }^{1}$ Czech Geological Survey, Klárov 3, 11821 Prague 1, Czech Republic; pavel.hanzl@geology.cz

${ }^{2}$ Ecole et Observatoire des Sciences de la Terre, Université de Strasbourg, UMR 7516 of CNRS, 1 rue Blessig, 67084 Strasbourg Cedex, France

${ }^{3}$ Institute of Petrology and Structural Geology, Charles University in Prague, Faculty of Science, Albertov 6, 12843 Prague 2, Czech Republic

${ }^{4}$ Institute of Paleontology and Geology, Mongolian Academy of Sciences, Ulaanbaatar 15160, Mongolia

${ }^{5}$ School of Geology and Mining Engineering, MUST, P.O. Box 654, Ulaanbaatar, Mongolia

${ }^{6}$ State Key Laboratory of Isotope Geochemistry, Guangzhou Institute of Geochemistry, Chinese Academy of Sciences, Guangzhou 510640, China

*Corresponding author

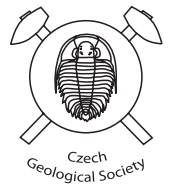

\begin{abstract}
Orthogneiss and meta-rhyolite bodies from different crustal levels of the Tseel Terrane in the Mongolian Altai were examined using multidisciplinary approach involving structural geology, whole-rock geochemistry and U-Pb zircon geochronology. The orthogneisses form sheet-like bodies parallel with dominant sub-horizontal metamorphic fabric which was heterogeneously verticalized along localized zones of deformation at boundaries of lower and middle crustal domains. Three samples of orthogneisses yielded Late Devonian LA-ICP-MS U-Pb zircon ages of $373 \pm 3,377 \pm 5$ and $379 \pm 2 \mathrm{Ma}(2 \sigma)$, which are interpreted as crystallization ages of felsic magmas. The meta-rhyolite displays poorly constrained, older U-Pb zircon ages of $380 \pm 4$ and $403 \pm 5 \mathrm{Ma}$, which are also considered as intrusive. Whole-rock geochemistry, including relatively little fractionated REE patterns, as well as radiogenic whole-rock Nd and zircon $\mathrm{Hf}$ isotopic signatures point to a rather primitive source of the granitic protoliths. The high-K calc-alkaline chemistry and LILE over HFSE enrichments in the NMORB-normalized spider plots indicate an arc-related origin. Juvenile character of the studied rocks was confirmed by Nd and $\mathrm{Hf}$ crustal residence ages that are mostly $0.8-0.9 \mathrm{Ga}$. The origin of the metaigneous rocks is interpreted in terms of partial melting of Neoproterozoic to Cambrian magmatic arc-derived material, probably dominated by immature psammitic sediments (graywackes). This study brings important arguments that the orthogneisses do not represent an old crystalline basement previously assumed in the Mongolian Altai. A model is proposed suggesting formation of mature and layered continental crust by syn-orogenic melting of youthful volcanosedimentary wedge and emplacement of sub-horizontal syn-orogenic magmatic sheets at all crustal levels during crustal-scale vertical shortening. The vertical shortening was probably connected to lithospheric-scale extensional event associated with massive heat influx and emplacement of juvenile magmas at the bottom of the crust. It is suggested that this mechanism represents potentially a viable model for cratonization of accretionary systems worldwide.
\end{abstract}

Keywords: Devonian orthogneiss, whole-rock geochemistry, $U-P b$ geochronology, crustal architecture, continental crust growth, Mongolian Altai

Received: 24 November, 2015; accepted: 22 January, 2016; handling editor: W.J. Xiao

\section{Introduction}

The Central Asian Orogenic Belt (CAOB) (Mossakovsky et al. 1994) is a giant accretionary system which developed from Late Proterozoic to Permian between the Siberian, Tarim and Sino-Korean blocks (Fig. 1) (e.g. Şengör et al. 1993; Dergunov 2001; Xiao et al. 2009). This orogen was formed by accretion of Cambrian, Ordovician and Devono-Carboniferous arcs, back-arcs and accretionary wedges (Badarch et al. 2002; Lamb and Badarch 2001; Kröner et al. 2007; Windley et al.
2007) and Grenville-age microcontinents (Demoux et al. 2009b; Rojas-Agramonte et al. 2011) of both Siberian and Gondwanan affinities (Cocks and Torsvik 2007; Wilhem et al. 2012).

The crustal growth of the CAOB is supposed to having been extremely efficient and rapid and was manifested by voluminous "juvenile" granitic intrusions (Jahn et al. 2000a; Jahn 2004; Yuan et al. 2007). The magmatic additions had an episodic character with several Palaeozoic magmatic pulses (Kovalenko et al. 2004). Based on Gorny and Rudny Altai magmatic evolution, they were 


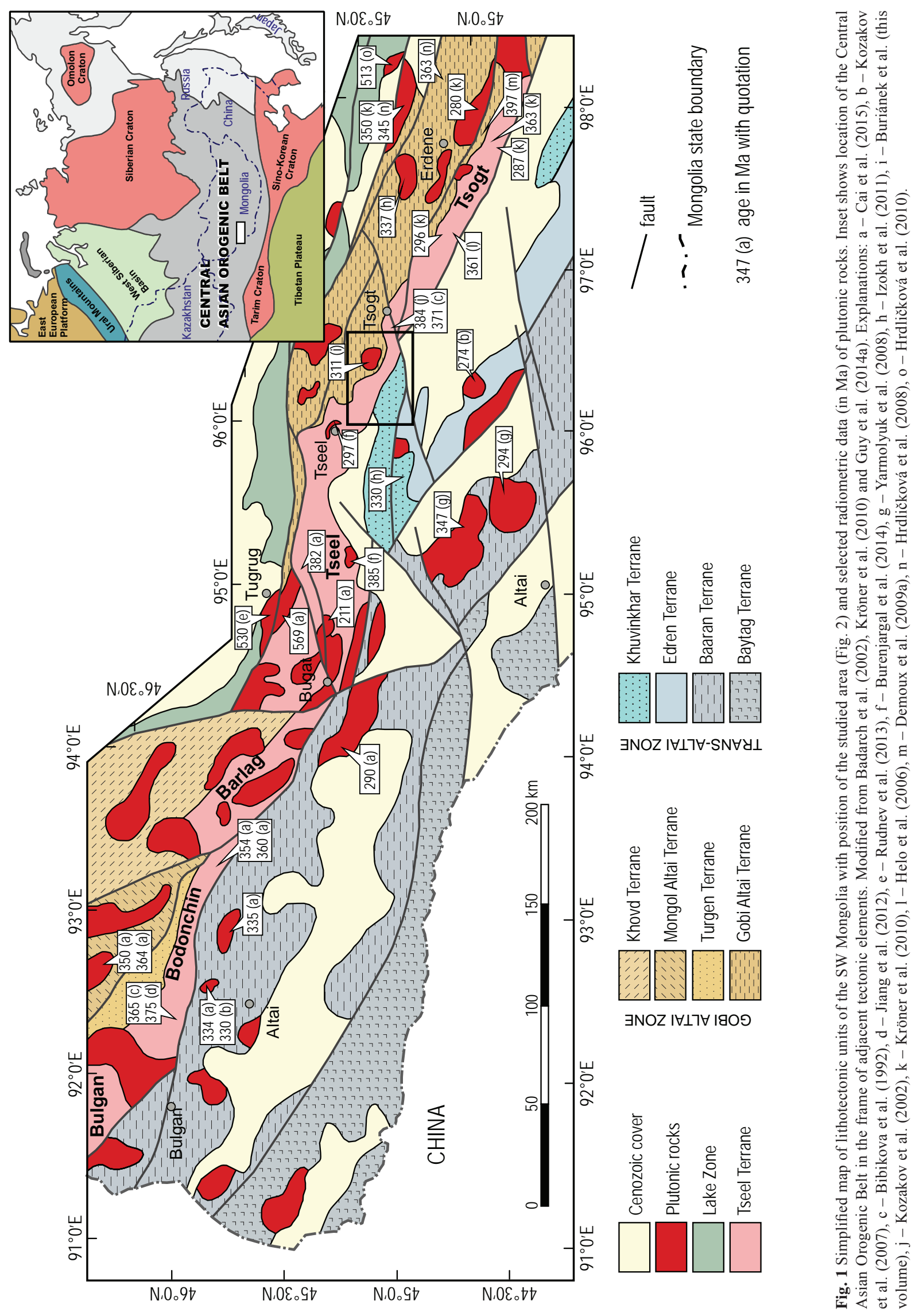


assigned to three global megacycles (Kruk et al. 2015): Late Cambrian (512-495 Ma), Devonian (410-362 Ma) and Late Palaeozoic-Early Mesozoic (340-190 Ma). Magmatism of the Mongolian part of CAOB also concentrated into several major magmatic pulses (Guy et al. 2014a; Cai et al. 2015): Late Cambrian to Early Ordovician (520-490 Ma), Devonian to Early Carboniferous (398-350 Ma), Late Carboniferous to Permian (317-289 Ma) and Triassic (c. 244-211 Ma). This magmatism was progressively younging to the SW (Fig. 1) as indicated by Late Cambrian-Ordovician arc granitoids intruding Proterozoic rocks (Lake Zone) in the north (Sal'nikova et al. 2001; Rudnev et al. 2009; Janoušek et al. 2015), Silurian to Devonian plutons intruding the Mongolian or Gobi Altai zones in the centre and Late Carboniferous to Permian plutons mainly occurring in the southerly oceanic terranes (Edren, Baaran, Khuvinkhar) to the south (e.g. Bibikova et al. 1992; Yarmolyuk et al. 2008).

The protracted, nearly continuous Late Silurian to Devonian magmatism in Chinese and Mongolian Altai was interpreted to have resulted from re-melting of old Precambrian basement due to massive influx of juvenile melts associated to massive basaltic magma underplating beneath old continental crust (e.g., Wang et al. 2009). This model is exclusively based on variable $\mathrm{Nd}$ and $\mathrm{Hf}$ isotopic signatures from different types of granitoids in Chinese Altai (Jahn et al. 2000b; Wang et al. 2009; Liu W et al. 2012) but it has been recently questioned by other authors who have argued that similar isotopic ratios can be produced by melting of accretionary prism composed of both continental and oceanic sediments (Sun et al. 2009; Xiao et al. 2009; Jiang et al. 2011, 2012; Long et al. 2012). The latter interpretation is supported by the lack of direct observations of deformed and metamorphosed basement rocks covered by Palaeozoic sediments in the Chinese and Mongolian Altai.

Recent study on the Mongolian Altai has revealed a presence of numerous highly deformed orthogneiss bodies within weakly metamorphosed sequences overlain by almost undeformed Carboniferous sediments as well as inside medium-grade to highly metamorphosed deep crustal series (Fig. 2). These highly deformed felsic gneisses represent an important lithology of Mongolian Altai crust suggesting a possible existence of an old metamorphosed basement covered by Devonian and Carboniferous sediments. These orthogneiss bodies can thus bring pivotal information regarding the nature of Mongolian Altai crust interpreted as a metamorphosedtype terrane of uncertain origin by Badarch et al. (2002) and Cocks and Torsvik (2007) or as a continental-type terrane by Wilhem et al. (2012).

This paper presents new geological, structural and geochemical data as well as zircon $\mathrm{U}-\mathrm{Pb}$ ages of various orthogneiss types from different crustal levels of the
Mongolian Altai. The characterization of these rocks is used to discuss the crustal structure and composition in the Mongolian Altai and, in particular, the potential presence of old basement.

\section{Geological setting}

\subsection{Geology of Tseel Terrane}

Tseel Terrane (Bibikova et al. 1992) is characterized by occurrence of metamorphosed rocks along the southern slopes of the Gobi, Mongolian and Chinese Altai and the Irtysh Shear Zone of East Kazakhstan (Kozakov et al. 2011). This unit is composed mainly of Palaeozoic rocks with polymetamorphic history (e.g. Kozakov et al. 2007; Jiang et al. 2012; Burenjargal et al. 2014) of uncertain affinity, located between Early Palaeozoic back-arc and arc terranes to the north and oceanic-type Khuvinkhar, Baaran and Edren terranes of the Trans-Altai Zone to the south (Badarch et al. 2002). Boundaries amongst major tectonic zones were reactivated by the Cenozoic, generally NW-SE trending faults (Cunningham 2005).

Bibikova et al. (1992) distinguished five parts of the Tseel Terrane which are, from the west to the east: Bulgan, Bodonchin, Barlag, Tseel and Tsogt blocks mutually separated by the late Cenozoic faults (Fig. 1). Demoux et al. (2009a) simplified subdivision of the Tseel Terrane into two, western and south-eastern regions.

The studied area is situated southwest of Tsogt village and west of the NE-SW oriented Tsogt Fault along the Sagsai river (Fig. 2). Here, the Tseel metamorphic core is bounded by the Devonian to Carboniferous volcanosedimentary complexes in the south and by low-grade Cambrian Tugrug Fm. (Markova 1975) in the north. This large unit composed of graywackes and volcanites is unconformably covered by Lower Devonian limestones and Carboniferous siliciclastic sediments. Its northern contact is generally concordant with faults of the Main Mongolian Lineament to the N and NW. The Tseel metamorphic core is dominated by the sequence of paragneisses and micaschists with subordinate intercalations of amphibolites, gabbroic and granitoid intrusions (Burenjargal et al. 2012). Metapelites of the Tseel Block were affected by Barrovian metamorphism ranging from biotite to kyanite/ sillimanite zones (Burenjargal et al. 2014). Peak $P-T$ conditions attaining the kyanite stability field were estimated to $560 \pm 10^{\circ} \mathrm{C}$ and $6.5 \pm 0.5 \mathrm{kbar}$ (Burenjargal et al. 2012).

The high-grade rocks of the so-called Tsogt Block (Bibikova et al. 1992) form a NW-SE trending belt south of the Tsogt village on the SE southern slopes of the Mongolian Altai. Here crops out strongly deformed sequence of migmatites, biotite and tonalite gneisses, orthogneisses, amphibolites and gabbros including small 


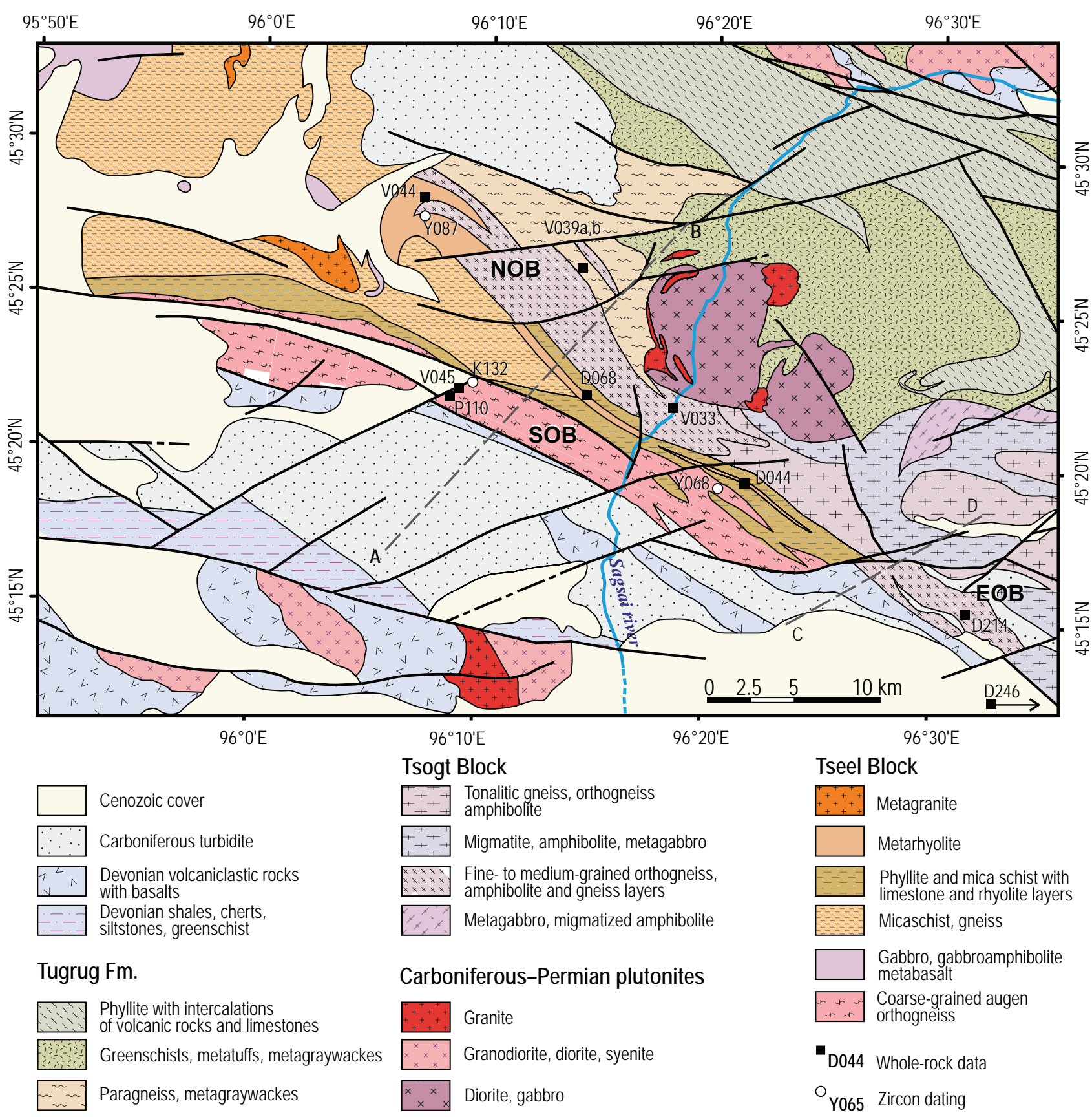

Fig. 2 Geological map of the eastern wedge of the Tseel Block with location of the samples.

lenses of granulites (Kozakov et al. 2002). Peak $P-T$ conditions of intermediate orthopyroxene-bearing rocks were estimated to $870{ }^{\circ} \mathrm{C}$ and $5.7 \mathrm{kbar}$ by the same authors and were associated with extensive melting of all lithologies.

\subsection{Previous geochronology of the Tseel Terrane}

Metamorphic complexes of the Mongolian and Gobi Altai were designated as Early Proterozoic to Riphean in older geological maps and Russian literature (e.g. Rauzer et al. 1987). Granitoids of the Tseel Terrane were first attributed to Devonian by Bibikova et al. (1992) who reported U-Pb zircon ages for granitoids of Bodonchin and Tsogt blocks ranging from $\sim 365$ to $371 \mathrm{Ma}$ (Tab. 1). Similar U-Pb zircon ages of $\sim 370-396$ Ma were subsequently obtained by Helo et al. (2006), Kröner et al. (2010), Burenjargal et al. (2014) and Cai et al. (2015) for granitic and tonalitic rocks from the Tsogt, Tseel and Bodonchin blocks. These magma crystallization ages have been corroborated by the $\sim 396$ Ma magmatic zircon age of rhyolite extrusions in the Tsogt Block (Demoux 


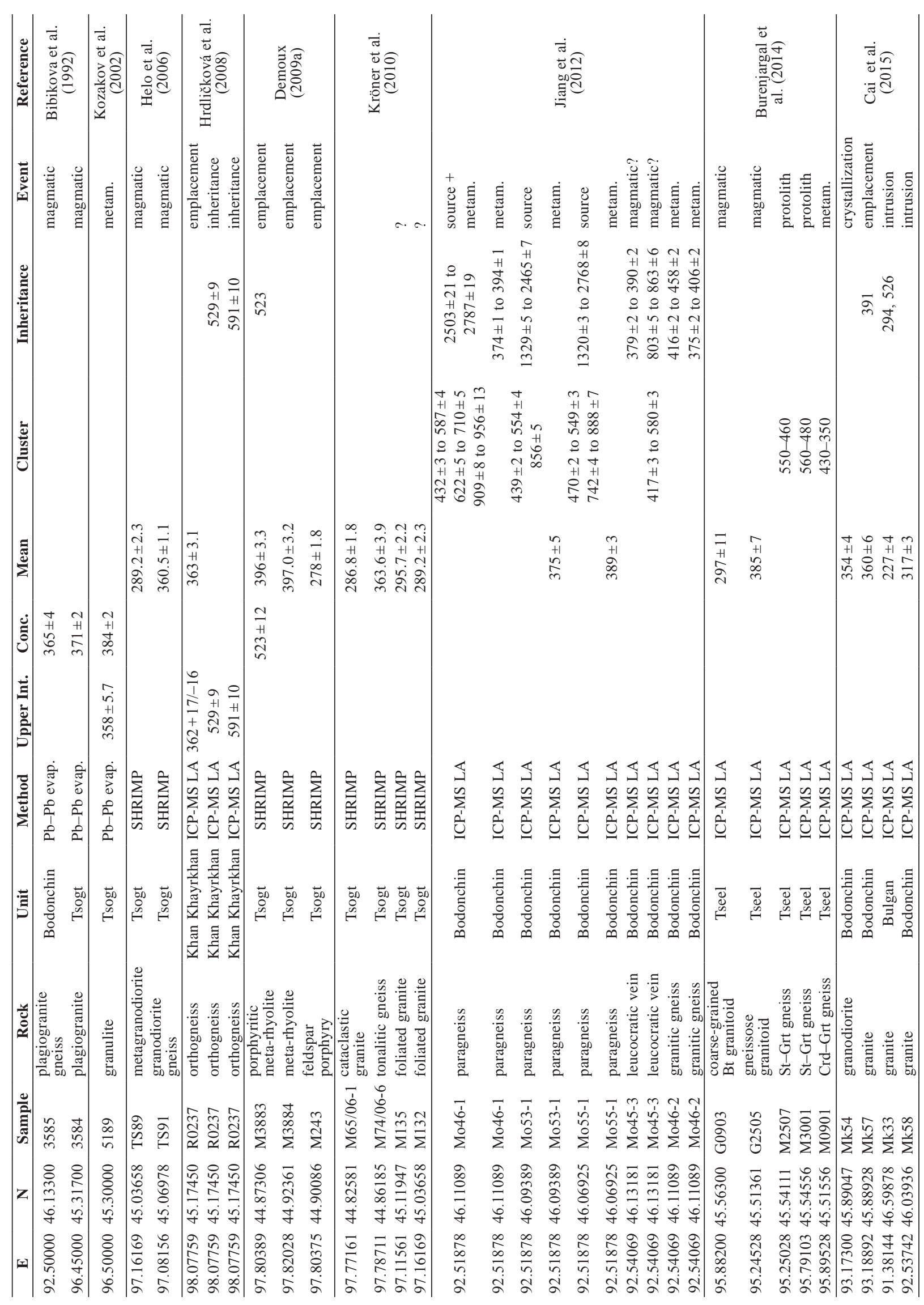


et al. 2009a). However, there is a significant number of ages suggesting an existence of Late Proterozoic to Early Palaeozoic protoliths (580-450 Ma) in the Bodonchin and Tseel blocks (Jiang et al. 2012; Burenjargal et al. 2014). Most authors agree that these protoliths were metamorphosed during Devonian (between $\sim 385$ and $377 \mathrm{Ma}$ ) in the whole Tseel Terrane based on U-Pb zircon dating of orthopyroxene granulites by Kozakov et al. (2002) or migmatitic paragneisses by Jiang et al. (2012) and Burenjargal et al. (2014). Typical feature of the Mongolian Altai is the presence of Late Carboniferous to Early Permian granitoids and pegmatites which intruded the Tseel Terrane at 320 to $260 \mathrm{Ma}$ (Kröner et al. 2010; Kozakov et al. 2011; Burenjargal et al. 2014 and this volume).

\section{Analytical techniques}

\subsection{Whole-rock geochemistry}

Eight samples of orthogneisses and three meta-rhyolites selected for analysis are listed in Tab. 2 and their location is shown in Fig. 2. Whole-rock analyses were performed in ActLabs (Vancouver, Canada) using the 4Lithoresearch procedure (http://www.actlabs.com). Major-element concentrations were obtained by Inductively-Coupled Plasma Optical Emission Spectrometry (ICP-OES), trace-element concentrations by Inductively-Coupled Plasma Mass Spectrometry (ICP-MS) following a lithium metaborate/ tetraborate fusion and a weak nitric acid solution. Such a procedure ensures that the entire sample is dissolved, including the refractory phases such as zircon or sphene. The geochemical data were plotted and recalculated using the GCDkit software (Janoušek et al. 2006).

\section{2. $\mathrm{Sr}-\mathrm{Nd}$ isotopes}

For the radiogenic isotope determinations, samples were dissolved using a combined $\mathrm{HF}-\mathrm{HCl}-\mathrm{HNO}_{3}$ digestion. Strontium and REE were isolated from the bulk matrix by the column chromatography techniques using TRU and Sr resins by Triskem Int. (Pin et al. 1994). The Nd was further separated from the REE fraction with Ln resin (Pin and Zalduegui 1997). Further analytical details were reported by Míková and Denková (2007). Isotopic analyses of Sr and Nd were performed on a Finnigan MAT 262 thermal ionization mass spectrometer housed at CGS in dynamic mode using a single Ta filament for $\mathrm{Sr}$ and in static mode using a double Re filament assembly for $\mathrm{Nd}$. The ${ }^{143} \mathrm{Nd} /{ }^{144} \mathrm{Nd}$ ratios were corrected for mass fractionation to ${ }^{146} \mathrm{Nd} /{ }^{144} \mathrm{Nd}=0.7219$ (Wasserburg et al. 1981), ${ }^{87} \mathrm{Sr} /{ }^{86} \mathrm{Sr}$ ratios assuming ${ }^{86} \mathrm{Sr} /{ }^{88} \mathrm{Sr}=0.1194$. External reproducibility is estimated from repeat analyses of the JNdil (Tanaka et al. 2000) $\left({ }^{143} \mathrm{Nd} /{ }^{144} \mathrm{Nd}=0.512107 \pm 28\right.$

Tab. 2 List of samples

\begin{tabular}{|c|c|c|c|c|}
\hline Sample & WG & S 84 & Unit & Description \\
\hline D044 & $96.364212 \mathrm{E}$ & $45.333801 \mathrm{~N}$ & RB & $\begin{array}{l}\text { Foliated porphyritic meta-rhyolite with transition to sericite schist, Qz, Pl, Kfs, Ms, Bt, Czo-Ep, } \\
\text { Zrn }\end{array}$ \\
\hline 068 & $96.230309 \mathrm{E}$ & $45.379753 \mathrm{~N}$ & $\mathrm{RB}$ & $\begin{array}{l}\text { Up to } 6 \mathrm{~m} \text { thick layer of fine-grained metatuff in sericite schists, leucocratic, Qz, Kfs, Pl, Ms, } \\
\text { Bt, Czo }\end{array}$ \\
\hline 14 & $523636 \mathrm{E}$ & $8 \mathrm{~N}$ & OB & Folded fine-grained orthogneiss intercalated with phyllite, Qz, Kfs, Pl, Chl, Ep, Ap, Opq \\
\hline D246 & $96.558487 \mathrm{E}$ & 4 & EOB & $0 \mathrm{~m}$ thick layer of medium-grained orthogneiss in Bt-Sil paragneiss; Qz, Pl, Kfs, Bt Opq, \\
\hline K132 & $96.153488 \mathrm{E}$ & $45.380497 \mathrm{~N}$ & SOB & $\begin{array}{l}\text { rthogneiss, intensively deformed under greenschist-facies conditions; Qz, Kfs, Pl, Bt, } \\
\text { Ms (Ser), Opq, Zrn }\end{array}$ \\
\hline 110 & $14212 \mathrm{I}$ & 45 . & SOB & hogneiss with tiny Fsp augen and Bt spots; Qz, Kfs, Pl, Bt, Czo-Ep, Aln, Ap, Ttn, \\
\hline 33 & $42 \mathrm{E}$ & $6 \mathrm{~N}$ & OB & ed orthogneiss; Qz, Pl, Kfs, Bt, Ms, Czo, Ap, Zrn \\
\hline ב39 & 96.250282 & $3 \mathrm{~N}$ & JOB & $\begin{array}{l}E \\
d e\end{array}$ \\
\hline V039 & $96.250282 \mathrm{E}$ & $3 \mathrm{~N}$ & NOB & Id Fsp phenocrysts; Qz, Pl, Kfs, Bt, Ms, \\
\hline V & $\mathrm{E}$ & & $\mathrm{RB}$ & gglomerate metatuff, orthogneiss texture in thin section, mm phenocrysts of Fsp and Qz \\
\hline V04 & $96.141678 \mathrm{E}$ & $45.376541 \mathrm{~N}$ & SOB & ned MME; Qz, Kfs, Pl, Bt, Ms (Ser), Czo-Ep, \\
\hline Y06 & $96.354187 \mathrm{E}$ & $45.329948 \mathrm{~N}$ & SOB & orphyroclasts; Qz, Kfs, Pl, Bt, Chl, Ep, Ap, \\
\hline Y08 & $96.115593 \mathrm{E}$ & $55969 \mathrm{~N}$ & NOB & $\begin{array}{l}\text { Felsic lapilli metatuff, leptynite with fine Fsp and Qz phenocrysts; Kfs, Qz, Pl, Ms, Bt, Zo, Zrn, } \\
\text { Ttn, Opq }\end{array}$ \\
\hline 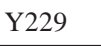 & $6.523758 \mathrm{E}$ & $5.26825 \mathrm{~N}$ & B & Very fine-grained orthogneiss with relics of Fsp porhyroclasts; Qz, Kfs, Pl, Ms, Ep, Opq, Zrn \\
\hline
\end{tabular}

RB - metamorphosed rhyolite in phyllites and NOB, NOB - Northern Orthogneiss Belt, EOB - Eastern Orthogneiss Belt, SOB - Southern Orthogneiss Belt, MME - mafic microgranular enclaves, mineral names abbreviations according to Whitney and Evans (2010). 
$(2 \sigma, \mathrm{n}=10))$ and NBS $987\left({ }^{87} \mathrm{Sr} /{ }^{86} \mathrm{Sr}=0.710239 \pm 26\right.$ $(2 \sigma, \mathrm{n}=17))$ standards. The decay constants applied to age-correct the isotopic ratios are from Steiger and Jäger $(1977-\mathrm{Sr})$ and Lugmair and Marti $(1978-\mathrm{Nd})$. The $\varepsilon_{\mathrm{Nd}}$ values were obtained using Bulk Earth parameters of Jacobsen and Wasserburg (1980), the two-stage Depleted Mantle Nd model ages $\left(T_{D M}^{N d}\right)$ were calculated after Liew and Hofmann (1988).

\subsection{U-Pb geochronology}

Four samples representing orthogneiss bodies of the eastern wedge of the Tseel Block were dated. Zircons were separated using heavy liquid and magnetic techniques, and then purified by hand picking under a binocular microscope (Central Geological Laboratory Ulaanbaatar). Zircon grains larger than $50 \mu \mathrm{m}$ were selected and mounted in epoxy resin. The mounts were then polished.

Cathodoluminescence (CL) imaging was taken on a CAMECA SX-100 electron microprobe equipped with a MonoCL3 CL spectrometer at the Institute of Petrology and Structural Geology, Charles University in Prague. Zircon dating used an ArF excimer $193 \mathrm{~nm}$ laser ablation system (Resolution M-50) coupled with a Nu Plasma HR MC-ICP-MS at the Department of Earth Sciences of the University of Hong Kong, following the analytical procedure described by Xia et al. (2011). Most analyses were performed with a beam diameter of $40 \mu \mathrm{m}, 5 \mathrm{~Hz}$ repetition rate and energy of $\sim 5 \mathrm{~J} / \mathrm{cm}^{2}$ per pulse. Zircon standard 91500 was used for calibration. The mass fractionation correction and isotopic results were calculated by ICPMSDataCal (version 7.0, Liu Y et al. 2008). The age calculations and concordia plots were done using ISOPLOT (version 3.7, Ludwig 2003). Individual analyses are presented with $1 \sigma$ error in the data table and in concordia diagrams, and uncertainties in mean age calculations are quoted at the $95 \%$ level $(2 \sigma)$.

\subsection{Hafnium isotopes}

Zircon Lu-Hf isotopic analysis was carried out by a Neptune Plus multi-collector ICP-MS equipped with a Resolution M-50 laser-ablation system at Guangzhou Institute of Geochemistry, Chinese Academy of Science. The measurements were conducted on selected large dated zircon grains, with a beam diameter of $45 \mu \mathrm{m}, 8 \mathrm{~Hz}$ repetition rate, and energy of $80 \mathrm{~mJ}$. Helium was used as carrier gas and some nitrogen was added in gas line to enhance the sample signal. The signal collection mode was one block with 200 cycles for each analysis, which consisted of 30s gas blank collection and 30s laser ablation. Isobaric interference of ${ }^{176} \mathrm{Lu}$ on ${ }^{176} \mathrm{Hf}$ was corrected by using a recommended ${ }^{176} \mathrm{Lu} /{ }^{175} \mathrm{Lu}$ ratio of 0.02655 (Machado and Simonetti 2001). Interference of ${ }^{176} \mathrm{Yb}$ on
${ }^{176} \mathrm{Hf}$ was corrected by using mass bias obtained on line and assuming ${ }^{176} \mathrm{Yb} /{ }^{172} \mathrm{Yb}=0.5887$ (Wu et al. 2006). Penglai zircon was used as the reference standard ( $\mathrm{Li}$ et al. 2010).

All Hf isotope data were recalculated with the decay constant of $1.867 \times 10^{-11} \mathrm{yr}^{-1}$ (Söderlund et al. 2004). The chondritic values of ${ }^{176} \mathrm{Hf} /{ }^{177} \mathrm{Hf}=0.0332$ and ${ }^{176} \mathrm{Lu} /{ }^{177} \mathrm{Hf}$ $=0.282772$ reported by Blichert-Toft et al. (1997) were employed for the calculation of $\varepsilon_{H f}^{t}$ values. The depleted mantle evolution line is defined by present-day ${ }^{176} \mathrm{Hf} /{ }^{177} \mathrm{Hf}$ of 0.28325 and ${ }^{176} \mathrm{Lu} /{ }^{177} \mathrm{Hf}$ of 0.0384 (Griffin et al. 2004). Because zircons were formed in granitic magma derived from felsic crust, a "crustal" model age is considered more meaningful (Griffin et al. 2004). In present work, this model age $\left(T_{D M}^{C}\right)$ was calculated for each zircon grain, assuming the mean ${ }^{176} \mathrm{Lu} /{ }^{177} \mathrm{Hf}$ ratio of 0.0093 for the upper continental crust (Amelin et al. 1999).

\section{Geology of orthogneiss bodies}

This study is focussed on felsic gneissic bodies of varied crustal levels defined according to degree of metamorphism and prevailing lithologies. The uppermost crustal level is represented by up to $3 \mathrm{~km}$ wide tectonic sheet of orthogneiss called here the Southern Orthogneiss Belt (SOB) which crops out between phyllites of the Tseel metamorphic core and Devono-Carboniferous volcanosedimentary complex of the Khuvinkhar Terrane to the south (Figs 1-2). Northern boundary of the SOB is marked by NNW-SSE trending zone of intense greenschist-facies deformation up to one kilometre wide. In contrast, the orthogneiss sheets at the southern SOB boundary were either folded together with low-grade metasediments or reworked by younger faults. Principal rock type forming the SOB is a coarse-grained biotite orthogneiss with large pink sigmoidal porphyroclasts (augen) of K-feldspars in less deformed varieties (Fig. 3a). Orthogneiss are compositionally rather homogenous with locally preserved mafic (microdiorite) enclaves. Coarsegrained orthogneisses show generally banded structure with quartz ribbons and recrystallized quartz-feldspathic matrix wrapping around the deformed K-feldspar phenocrysts. Modal composition includes quartz, K-feldspar, plagioclase, biotite and muscovite; sericite, chlorite and zoisite are secondary. Ilmenite, magnetite, zircon and apatite are the common accessoric minerals.

Middle crustal level is represented by sheets of fine- to medium-grained orthogneisses and their medium-grade host rocks exposed along the NE margin of mediumgrade Tseel metamorphic core. This NW-SE oriented belt is called here the Northern Orthogneiss Belt (NOB) and consists of tabular orthogneiss bodies intercalated with two-mica paragneisses, mica-schists and amphibolites. Intrusive character of granite precursor of these gneisses 

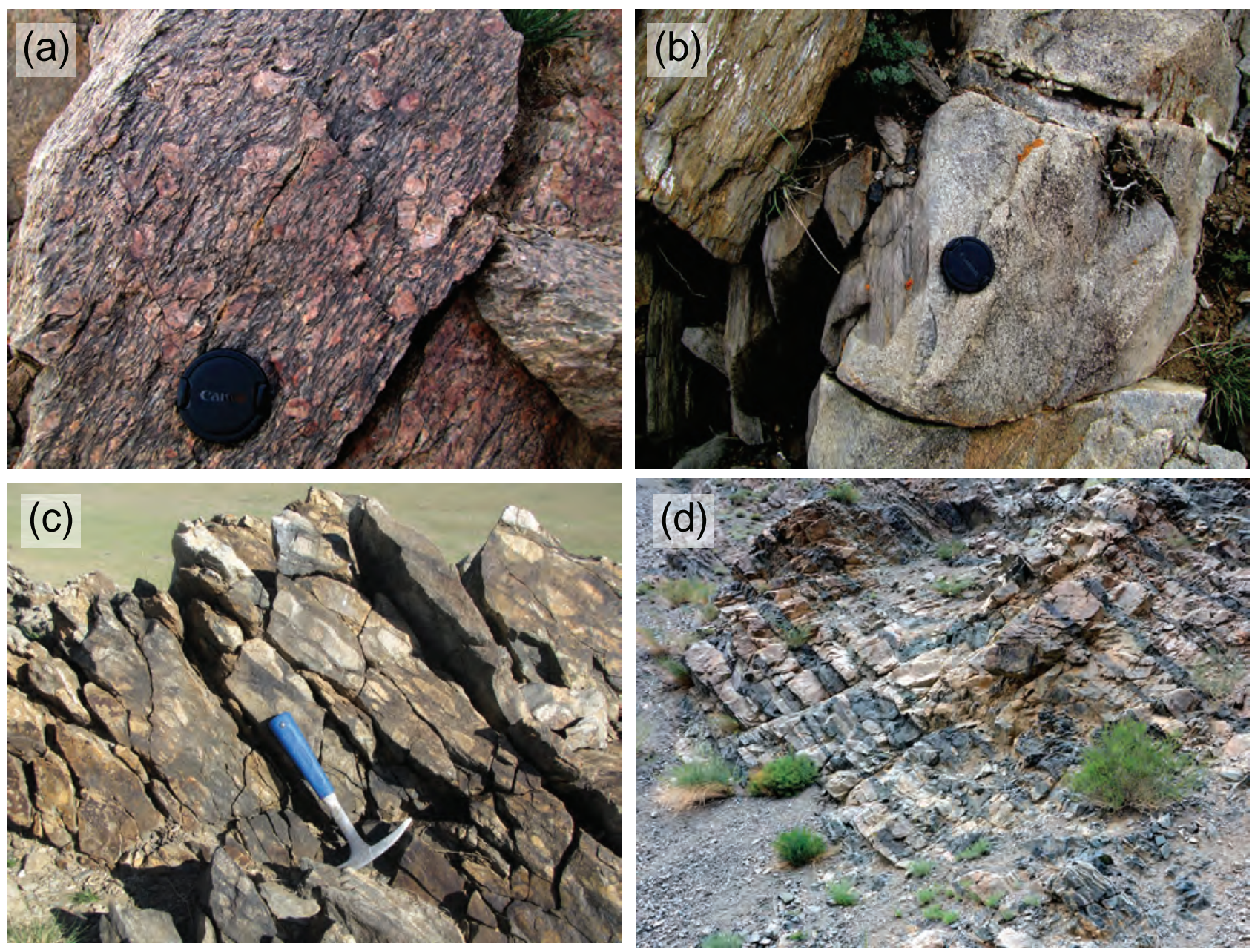

Fig. 3 Characteristic exposures of the studied rocks. a - Coarse-grained augen orthogneiss of the SOB; $\mathbf{b}$ - Preserved xenolith in metagranite of the NOB; $\mathbf{c}$ - Meta-rhyolite from the fold closure of the NOB; $\mathbf{d}$ - Alternation of orthogneiss and amphibolite in the EOB.

is confirmed by the occurrence of metapelite xenoliths in less deformed varieties (Fig. 3b). The NW termination of the NOB is characterized by transition of orthogneiss to meta-rhyolite with locally preserved agglomerate textures (Fig. 3c). In contrast, in the SE part of the NOB the orthogneiss sheets alternate with amphibolites and high-grade paragneisses. The orthogneiss forming the central part of the NOB shows a characteristic granoblastic polygonal structure with homogenous grain size $(0.2-0.4 \mathrm{~mm})$ and sub-equant, irregularly shaped mineral grains. The rock consists of quartz, K-feldspar, plagioclase, muscovite, biotite \pm garnet, secondary chlorite and epidote together with accessoric ilmenite, titanite, and zircon. Relics of corroded phenocrysts of K-feldspars and oscillatory-zoned plagioclases are preserved locally. Narrow meta-rhyolite sheet is also exposed inside the phyllites between the NOB and SOB. Here, quartz grains prevail over feldspars in the granoblastic matrix, which contains feldspar and quartz porphyroclasts. The foliation is defined by preferred orientation of biotite and muscovite flakes.
The deepest crustal level orthogneiss bodies form an important part of the highly metamorphosed Tsogt Block (Eastern Orthogneiss Belt - EOB). Here, texturally variable orthogneiss types are intercalated with layers of amphibolites and paragneisses (Fig. 3d). These sequences lithologically resemble those occurring in $\mathrm{SE}$ termination of NOB. The main orthogneiss type is formed by granoblastic quartz-feldspar matrix with tiny (up to $1 \mathrm{~mm}$ ) porphyroblasts of quartz and K-feldspar and less abundant biotite with secondary epidote and chlorite.

\section{Structural characteristics}

Structural data were divided in four structural domains (Fig. 4) according to previously distinguished crustal levels and prevailing structural style: the high-grade infrastructure (HGI), medium-grade infrastructure (MGI), southern low-grade domain (SLG) and the zone of localized high-intensity deformation (DZ) separating the 
Fig. 4 Sketch of crustal domains on the contact of the Tseel and Tsogt blocks based on the Landsat TM, bands 453 . SLG - Southern low-grade domain, DZ - Deformation zone, MGI - Mediumgrade infrastructure, HGI - High-grade infrastructure, CI - Carboniferous intrusions, EOB - Eastern Orthogneiss Belt, SOB - Southern Orthogneiss Belt, NOB - Northern Orthogneiss Belt.

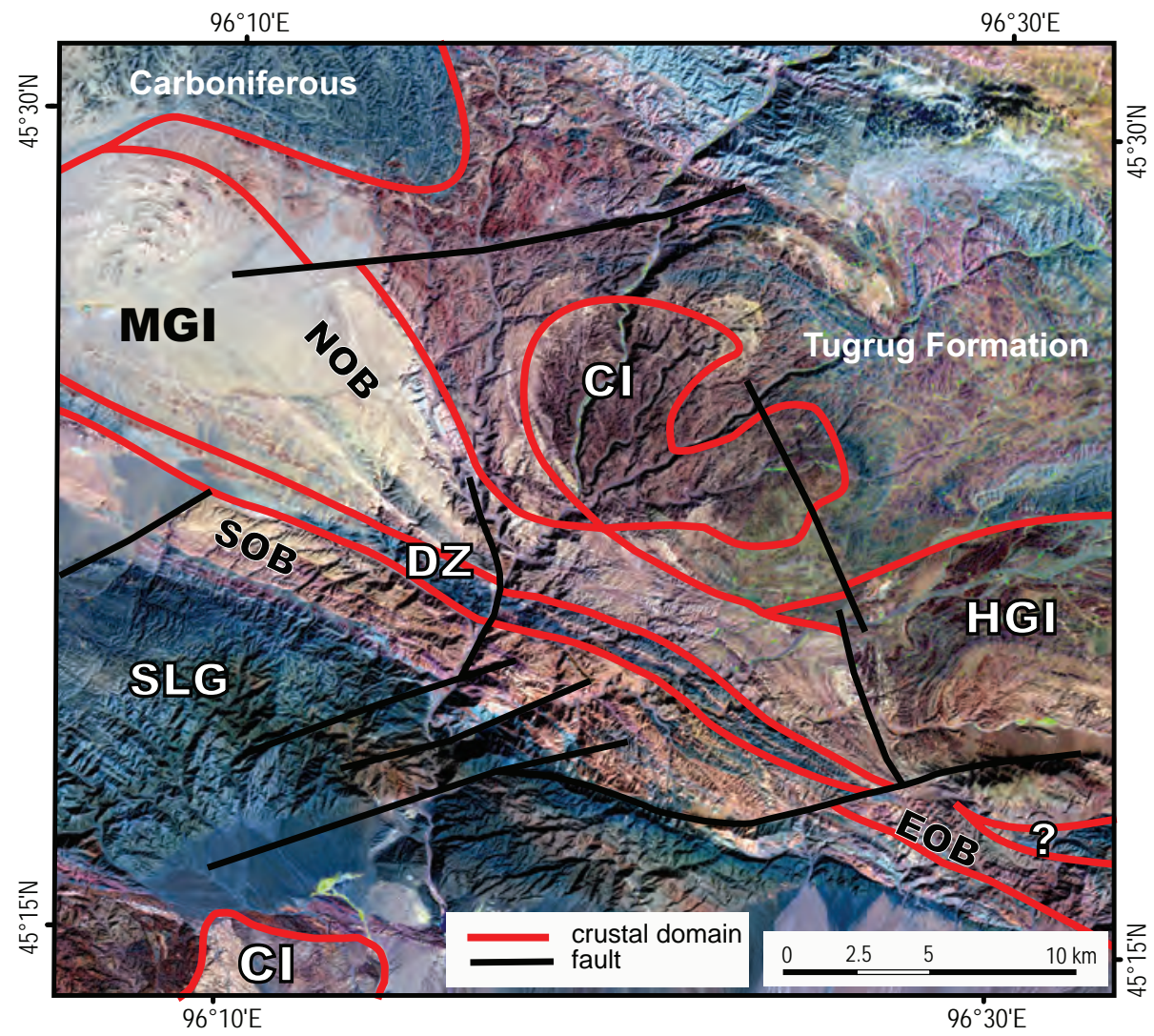

southern from both infrastructure domains. These structural domains show sequence of three heterogeneously developed deformation fabrics. The $\mathrm{S}_{1}$ metamorphic fabric reworking $S_{0}$ stratification is only rarely preserved being almost entirely transposed by ubiquitous foliation $\mathrm{S}_{2}$ associated with recumbent isoclinal $\mathrm{F}_{2}$ folds. All structures were affected by late upright folding $\mathrm{F}_{3}$ connected with greenschist-facies, steep cleavage $S_{3}$ in several localized deformation zones.

\subsection{High-grade infrastructure (HGI)}

The structural record is represented by NW-SE striking compositional layering defined by alternation of orthogneiss sheets, amphibolite and metasedimentary layers parallel to metamorphic foliation $\mathrm{S}_{2}$ dipping steeply to gently either to the NE or SW (Fig. 5). This composite fabric is associated with recumbent, close to isoclinal folds $\mathrm{F}_{2}$ (Figs 6a, 7) with axes plunging either to the NE or gently to the WSW, while mineral lineations are mainly plunging to the NE. The $\mathrm{F}_{2}$ folds are similar in geometry and reveal cuspate-lobate relationships between these two lithologies suggesting low viscosity contrast between gneisses and schists during folding and $\mathrm{D}_{2}$ transposition. This implies that the recumbent $\mathrm{F}_{2}$ folding occurred at relatively elevated temperatures allowing convergence of viscosities of two rheologically contrasting rock types. The girdle pattern of poles to the $S_{2}$ fabrics originated through $D_{3}$ refolding of originally gently NW-dipping package of gneisses by open to close upright folds $\mathrm{F}_{3}$ of various scales (Fig. 6b) with WNW-trending horizontal hinges (Figs 5,7).

\subsection{Medium-grade infrastucture (MGI)}

In this unit, the structural record (Fig. 5) is represented by highly foliated orthogneisses alternating with micaschists and amphibolites (Fig. 6c). The orthogneisses of the NOB form NW-SE trending sheet-like bodies, which terminate in the NW by a brachyanticlinal fold closure gently plunging to the $\mathrm{N}$ (Fig. 2). The $\mathrm{S}_{2}$ foliation defined by compositional layering and penetrative schistosity is steeply dipping either to the NE or SW and forms uncomplete NE-SW oriented girdle (Fig. 5). The $\mathrm{S}_{2}$ fabric bears mainly NW to SE plunging stretching and mineral lineation $\mathrm{L}_{2}$ (Fig. 5) parallel to $\mathrm{F}_{2}$ fold hinges. High degree of $\mathrm{D}_{2}$ transposition is indicated by relics of hinges of rootles folds (Fig. 7). Meta-rhyolites in the north of the NOB and associated phyllites are concordant to higher grade gneisses to the SE and show similar polyphase deformation history. Similarly to HGI, all MGI lithologies are reworked by upright NW-SE trending $\mathrm{F}_{3}$ folds with sub-horizontal hinges (Figs 5, 7). 


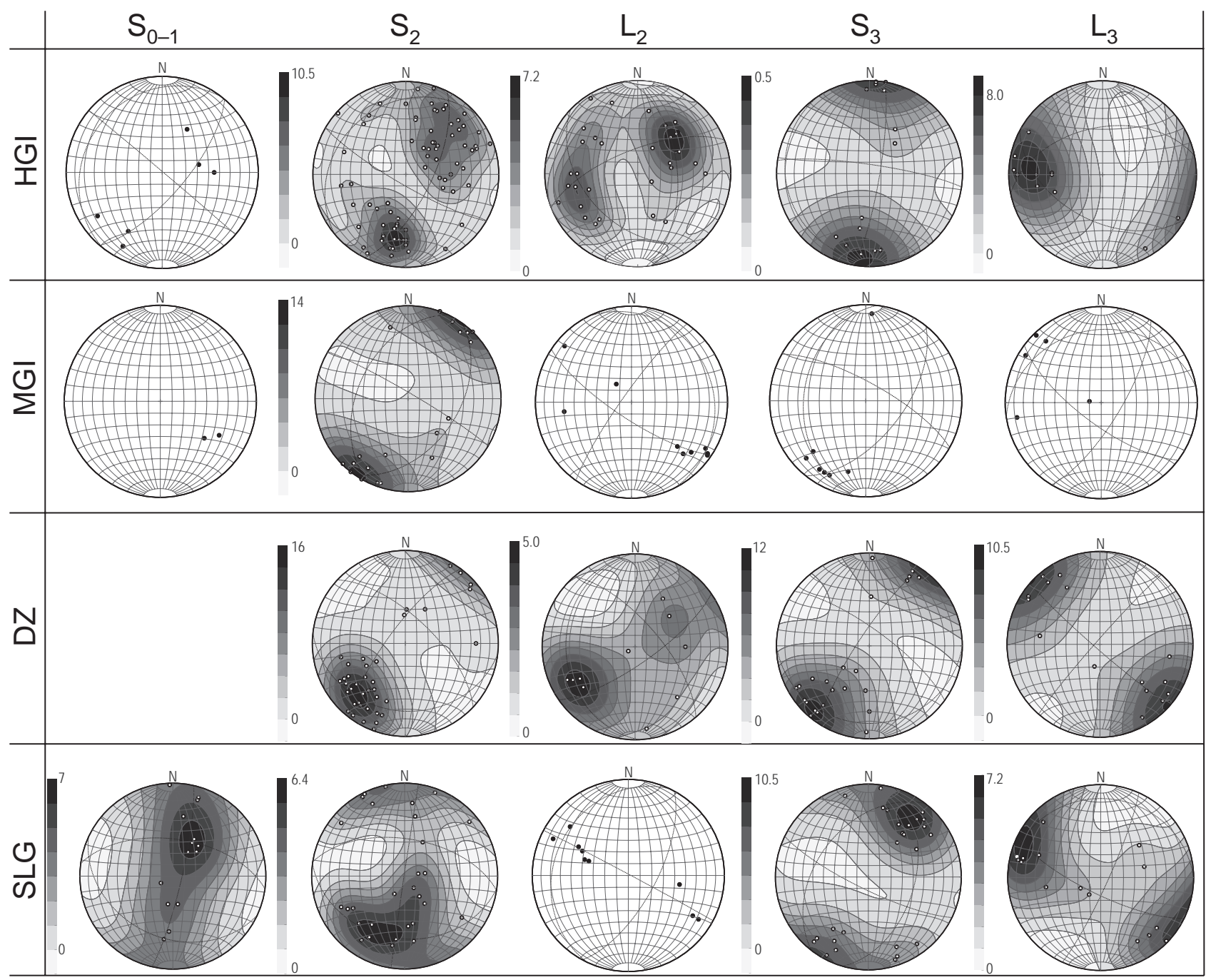

Fig. 5 Orientation diagrams of selected structures in geological domains on the contact of the Tseel and Tsogt blocks. Planes plotted as poles, lower hemisphere, Schmidt projection. SLG - Southern low-grade domain, DZ - Deformation zone, MGI - Medium-grade infrastructure, HGI High-grade infrastructure.

\subsection{Zone of localized high-intensity deformation (DZ)}

The $\mathrm{DZ}$ is a narrow $\mathrm{E}-\mathrm{W}$ oriented zone of intense $\mathrm{D}_{3}$ deformation separating the medium-grade infrastructure from the southerly low-grade domain (Fig. 4). It affected the northern part of the SOB and is represented by pervasive greenschist-facies deformation of the coarse-grained augen orthogneiss producing ultramylonites and phyllonites. This deformation was associated with development of ubiquitous NW-SE striking mylonitic foliation dipping homogeneously to the $\mathrm{NE}$ as well as mineral and aggregate lineation which forms a NW-SE trending girdle with SW maximum (Fig. 5). However, this apparently simple structural pattern has resulted from folding and steepening of the $S_{2}$ fabric, which is commonly preserved in limbs of upright NW-SE trending $\mathrm{F}_{3}$ folds. Here, the steep NW-SE trending $\mathrm{S}_{2}$ foliation bears min- eral lineation plunging either steeply NE or to the SW, i.e. almost orthogonally to orientation of $F_{3}$ folds (Fig. 5).

\subsection{Southern low-grade domain (SLG)}

The $\mathrm{D}_{3}$ deformation intensity rapidly decreases to the south where the SLG (Fig. 4) exhibits the most complete structural record from the whole studied area. The poles to bedding $\mathrm{S}_{0}$ in the Carboniferous sediments and poles to $\mathrm{S}_{0-1}$ fabric in the Devonian volcanics and sediments form a wide NE-SW trending girdle (Fig. 5). The $\mathrm{S}_{2}$ foliation is best preserved in the eastern part of the studied area, close to the MGI boundary (Fig. 7). Here, this low-grade fabric is dipping sub-horizontally or to the SW under various angles. The poles of $\mathrm{S}_{2}$ thus also form NE-SW trending girdle (Fig. 5). Bedding surfaces $\mathrm{S}_{0}$ in Carboniferous sediments, $S_{0-1}$ and $S_{2}$ fabrics of underlying Devonian metasediments and phyllites of non-specified 

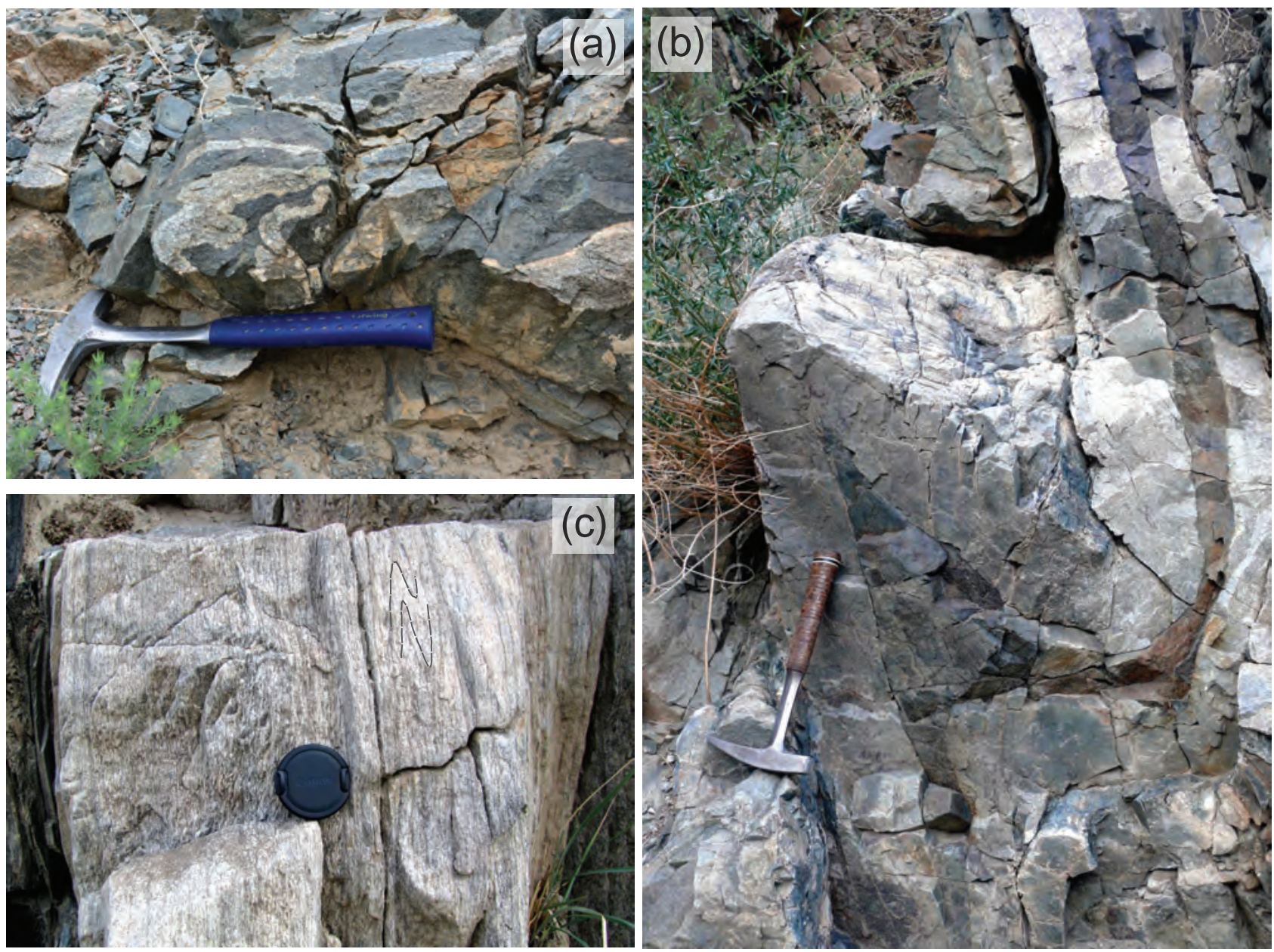

Fig. 6 Examples of fold structures in orthogneiss bodies. a - Close to isoclinal folds in the EOB; $\mathbf{b}$ - Upright folds in the EOB; $\mathbf{c}-$ Relicts of rootless folds in the medium-grained orthogneiss of the NOB.

age are reworked by sub-vertical, nearly NW-SE trending cleavage associated with upright open to close $\mathrm{F}_{3}$ folds (Fig. 5) which are parallel with corresponding structures in the DZ. The NNE-SSW trending girdle of poles of $S_{1}, S_{2}$ schistosity and $S_{0}$ bedding surfaces form $\beta$-axis parallel to axes of mesoscopic $\mathrm{F}_{3}$ folds implying that both bedding and $\mathrm{S}_{1-2}$ foliations have been sub-horizontal prior to the upright $\mathrm{F}_{3}$ folding (Figs 5,7 ).

In summary, the structural domains forming the studied area reveal polyphase tectonic evolution of orthogneiss bodies, their host phyllites and mica schists as well as southerly Devono-Carboniferous sediments. All structural domains show a sequence of three deformation events except Carboniferous sediments lacking $D_{1-2}$ structures. Importantly, the gneisses form sheet-like bodies, which were aligned parallel to originally sub-horizontal $\mathrm{S}_{2}$ fabric (Fig. 7). Such a crustal-scale layering developed across the whole crustal column and metamorphic gradient. Finally, this horizontal layering was heterogeneously reworked and steepened along zones of $\mathrm{D}_{3}$ deformation, from which the "DZ" was the most important (Fig. 4).

\section{Results of geochemistry and geochronology}

Orthogneiss and rhyolite bodies were sampled from all crustal levels of the studied area. The sampling locations are shown in Fig. 2 and description of samples is presented in Tab. 2.

\subsection{Whole-rock geochemistry}

Orthogneisses can be classified on the basis of the mesonormative Q'-ANOR diagram (Streckeisen and Le Maitre 1979) (Fig. 8a) as granodiorite (SOB), granodiorite to tonalite (NOB) and granite to granodiorite (EOB). While the sample of the NOB meta-rhyolite indeed corresponds to rhyolite in the $\mathrm{SiO}_{2}-\mathrm{Zr} / \mathrm{TiO}$ plot (Winchester and Floyd 1977) (Fig. 8b), the other meta-rhyolites straddle the boundary of the adjacent rhyodacite/dacite field.

Silica abundances (Tab. 3) range between 72.3 and 74.6 wt. \% in rhyolites and between 67.6 and $77.0 \mathrm{wt}$. $\%$ in orthogneisses. In general, the rocks from the SOB 


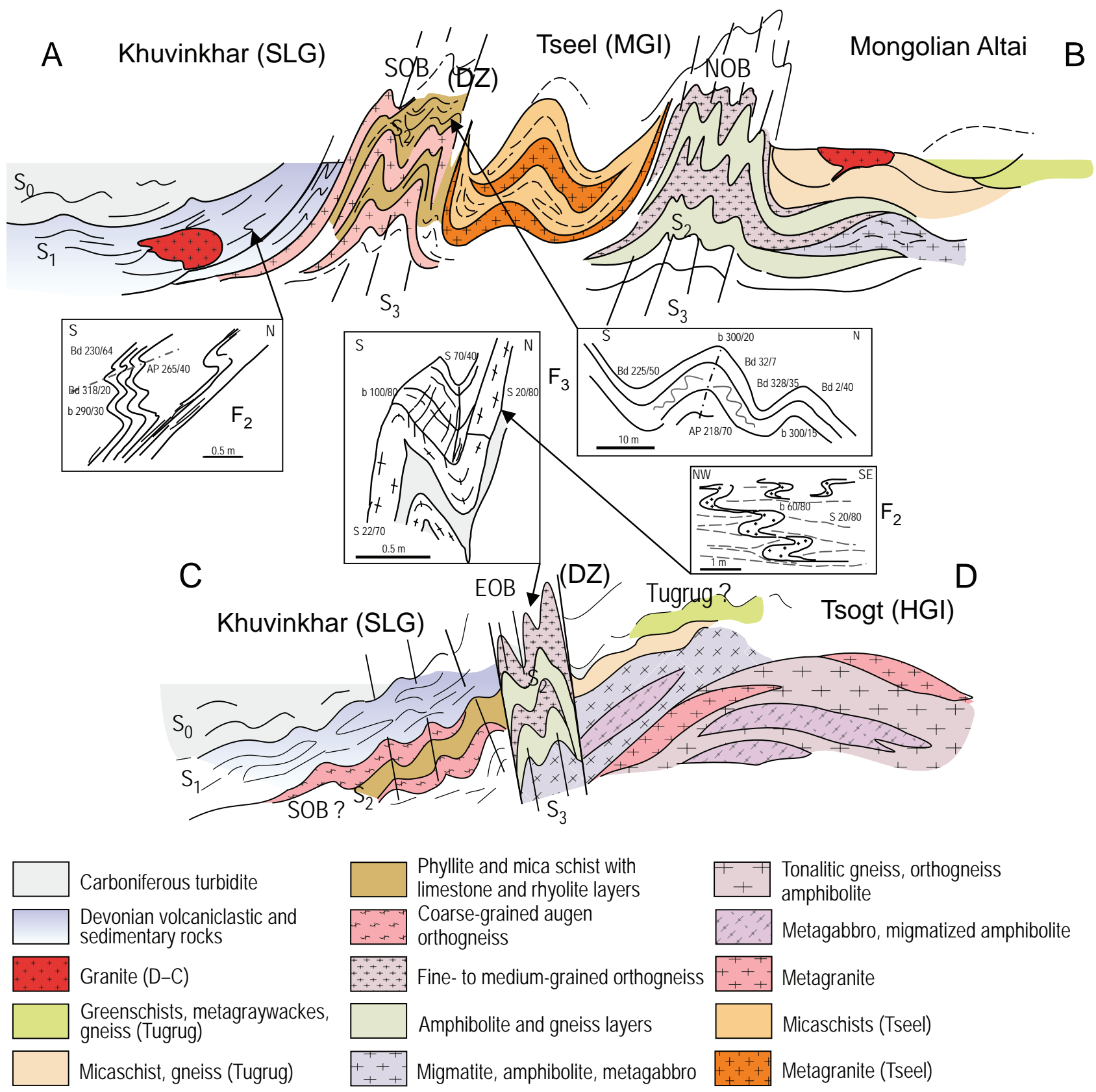

Fig. 7 Idealized cross-sections along profiles A-B and C-D in Fig. 2. For explanation of abbreviations, see Fig. 4.

are the least, and rhyolites with the EB orthogneisses the most, siliceous. The $\mathrm{K}_{2} \mathrm{O} / \mathrm{Na}_{2} \mathrm{O}$ ratios (by weight) are variable, but mostly less than unity $(0.23-1.36$, median $=$ 0.69 ; only the NOB orthogneiss $\mathrm{V} 039 \mathrm{a}$ has $\mathrm{K}_{2} \mathrm{O} / \mathrm{Na}_{2} \mathrm{O}=$ 4.62). This may point to a possible variability of alkalis in some of the samples.

Based on the cation plot of Jensen (1976), the rocks form a single calc-alkaline suite (Fig. 8c). In the Co-Th diagram (Hastie et al. 2007) (Fig. 8d), a more robust replacement for $\mathrm{SiO}_{2}$ vs. $\mathrm{K}_{2} \mathrm{O}$ plot (Peccerillo and Taylor 1976) for altered/metamorphosed igneous rocks, all samples except V039b show a high-K calc-alkaline chemistry.
All samples are subaluminous, as shown by the A/ CNK index (Shand 1943) ranging between 0.98 and 1.11. The only exception represents the sample V039a with an elevated $\mathrm{A} / \mathrm{CNK}$ value (1.38). The $\mathrm{Rb} / \mathrm{Sr}$ ratios range $0.32-0.42$ for meta-rhyolites, but are rather variable but still low for orthogneisses $(0.07-1.16)$ (Tab. 4).

In the NMORB-normalized (Sun and McDonough 1989) spider diagrams, all metaigneous rocks are mutually well comparable (Fig. 9). All are characterized by strong enrichment in Large Ion Lithophile Elements (LILE), $\mathrm{U}, \mathrm{Th}, \mathrm{Pb}$, and pronounced depletion in High 
Fig. 8 Classification of orthogneisses and meta-rhyolites. a - Q'-ANOR diagram (Streckeisen and Le Maitre 1979) based on the Improved Granite Mesonorm (Mielke and Winkler 1979); 2 - alkali feldspar granite, 3 - granite, 4 - granodiorite, 5 - tonalite, $6^{*}$ quartz alkali feldspar syenite, $7^{*}$ quartz syenite, $8^{*}$ - quartz monzonite, 9* - quartz monzodiorite/quartz monzogabbro, $10 *$ - quartz diorite/quartz gabbro, 6 - alkali feldspar syenite, 7 - syenite, 8 - monzonite, 9 - monzodiorite/monzogabbro 10 - diorite/ gabbro. b - Zr/TiO 2 vs. $\mathrm{SiO}_{2}$ plot (Winchester and Floyd 1977); TrAn = trachyandesite, $\mathrm{AB}=$ alkali basalt . c - (Al-Fe + Ti-Mg ternary diagram of Jensen (1976). d - Co-Th plot of Hastie et al. (2007); $\mathrm{B}=$ basalt, $\mathrm{BA} / \mathrm{A}=$ basaltic andesite and andesite, $\mathrm{D} / \mathrm{R}^{*}=$ dacite and rhyolite $(*$ latites and trachytes also fall in the $\mathrm{D} / \mathrm{R}$ field).

Field Strength Elements (HFSE: Nb, P and Ti); the normalized HREE contents are mostly close to unity. The
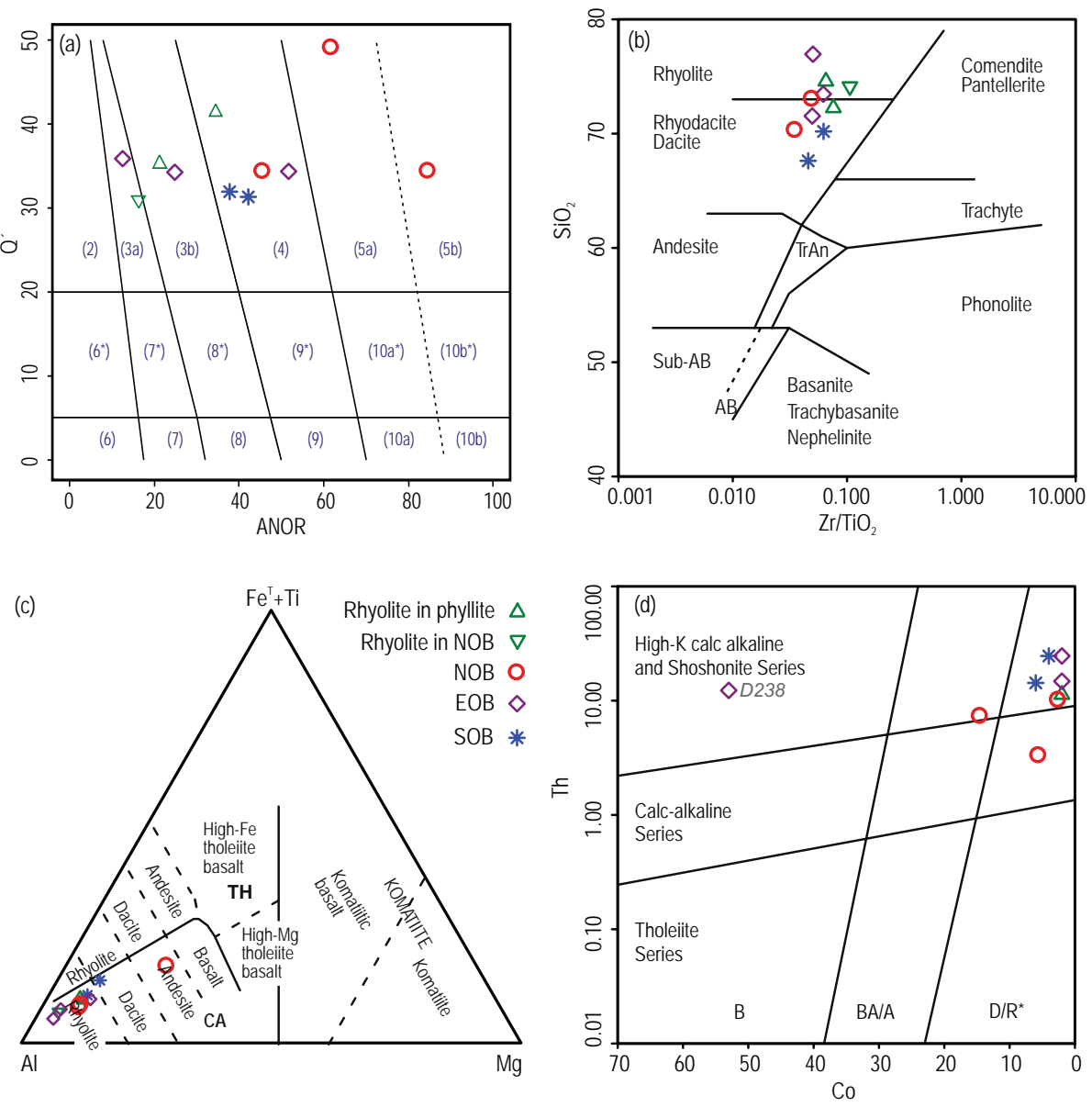

Tab. 3 Major-element whole-rock geochemical analyses (wt. \%)

\begin{tabular}{|c|c|c|c|c|c|c|c|c|c|c|c|}
\hline & V039a & V039b & V033 & P110 & V045 & D238 & D246 & D214 & D044 & V044 & D068 \\
\hline Region & NOB & NOB & NOB & SOB & SOB & EOB & EOB & EOB & $\mathrm{RB}$ & $\mathrm{RB}$ & $\mathrm{RB}$ \\
\hline Petrology & $\begin{array}{l}\text { ortho- } \\
\text { gneiss }\end{array}$ & $\begin{array}{l}\text { ortho- } \\
\text { gneiss }\end{array}$ & $\begin{array}{l}\text { ortho- } \\
\text { gneiss }\end{array}$ & $\begin{array}{l}\text { tonalite } \\
\text { ortho- } \\
\text { gneiss }\end{array}$ & $\begin{array}{l}\text { ortho- } \\
\text { gneiss }\end{array}$ & $\begin{array}{l}\text { ortho- } \\
\text { gneiss }\end{array}$ & $\begin{array}{l}\text { ortho- } \\
\text { gneiss }\end{array}$ & $\begin{array}{l}\text { ortho- } \\
\text { gneiss }\end{array}$ & $\begin{array}{l}\text { meta- } \\
\text { rhyolite }\end{array}$ & $\begin{array}{l}\text { meta- } \\
\text { rhyolite }\end{array}$ & $\begin{array}{l}\text { meta- } \\
\text { rhyolite }\end{array}$ \\
\hline $\mathrm{SiO}_{2}$ & 68.61 & 70.31 & 73.03 & 67.62 & 70.19 & 71.54 & 73.46 & 76.95 & 72.25 & 74.12 & 74.58 \\
\hline $\mathrm{TiO}_{2}$ & 0.61 & 0.34 & 0.36 & 0.51 & 0.40 & 0.39 & 0.20 & 0.17 & 0.33 & 0.20 & 0.26 \\
\hline $\mathrm{Al}_{2} \mathrm{O}_{3}$ & 13.98 & 16.17 & 13.36 & 14.48 & 15.02 & 14.12 & 13.61 & 12.09 & 13.20 & 13.16 & 12.76 \\
\hline $\mathrm{Fe}_{2} \mathrm{O}_{3}$ & 5.81 & 2.26 & 1.69 & 3.77 & 2.85 & 2.42 & 1.74 & 1.05 & 2.18 & 1.51 & 2.30 \\
\hline $\mathrm{MnO}$ & 0.19 & 0.03 & 0.04 & 0.04 & 0.09 & 0.05 & 0.04 & 0.02 & 0.08 & 0.02 & 0.06 \\
\hline $\mathrm{MgO}$ & 3.34 & 0.93 & 0.77 & 1.00 & 0.87 & 0.96 & 0.28 & 0.20 & 0.70 & 0.25 & 0.58 \\
\hline $\mathrm{CaO}$ & 3.13 & 3.54 & 1.25 & 2.58 & 2.63 & 1.62 & 1.42 & 0.71 & 0.78 & 0.79 & 1.24 \\
\hline $\mathrm{Na}_{2} \mathrm{O}$ & 0.67 & 4.50 & 5.36 & 3.43 & 3.12 & 5.06 & 3.55 & 4.63 & 4.51 & 4.43 & 4.01 \\
\hline $\mathrm{K}_{2} \mathrm{O}$ & 3.10 & 1.04 & 1.67 & 3.56 & 4.23 & 1.74 & 4.22 & 3.19 & 2.96 & 4.14 & 2.42 \\
\hline $\mathrm{P}_{2} \mathrm{O}_{5}$ & 0.09 & 0.11 & 0.06 & 0.13 & 0.12 & 0.08 & 0.05 & 0.01 & 0.06 & 0.05 & 0.04 \\
\hline LOI & 1.18 & 0.85 & 0.48 & 1.52 & 1.20 & 0.42 & 0.52 & 0.40 & 0.83 & 0.31 & 1.09 \\
\hline$\Sigma$ & 100.71 & 100.08 & 98.07 & 98.64 & 100.72 & 98.40 & 99.09 & 99.42 & 97.88 & 98.98 & 99.34 \\
\hline $\mathrm{K}_{2} \mathrm{O} / \mathrm{Na}_{2} \mathrm{O}$ & 4.63 & 0.23 & 0.31 & 1.04 & 1.36 & 0.34 & 1.19 & 0.69 & 0.66 & 0.93 & 0.60 \\
\hline $\mathrm{A} / \mathrm{CNK}$ & 1.4 & 1.1 & 1.0 & 1.0 & 1.0 & 1.1 & 1.1 & 1.0 & 1.1 & 1.0 & 1.1 \\
\hline $\mathrm{CaO} / \mathrm{Na}_{2} \mathrm{O}$ & 4.67 & 0.79 & 0.23 & 0.75 & 0.84 & 0.32 & 0.40 & 0.15 & 0.17 & 0.18 & 0.31 \\
\hline mg\# & 53.3 & 44.9 & 47.4 & 34.5 & 37.7 & 44.0 & 24.2 & 27.4 & 38.9 & 24.7 & 33.3 \\
\hline
\end{tabular}

Abbreviations for regional units as in Tab. 2

meta-rhyolites differ from the orthogneisses by slightly lower $\mathrm{Cs}, \mathrm{Rb}, \mathrm{U}$ and Th contents. 
Chondrite-normalized (Boynton 1984) REE patterns of orthogneisses are generally U-shaped (convexdownward), being characterized by a moderate degree of LREE fractionation and mostly weak negative Eu anomalies $\left(\mathrm{La}_{\mathrm{N}} / \mathrm{Sm}_{\mathrm{N}}=3.2-7.4, \mathrm{La}_{\mathrm{N}} / \mathrm{Yb}_{\mathrm{N}}=7.3-9.4, \mathrm{Eu} / \mathrm{Eu}^{*}=\right.$ $0.85-0.55, \Sigma \mathrm{REE}=110-238 \mathrm{ppm})($ Tab. 5, Fig. 10). The only exceptions represent the samples V039b (NOB) and D214 (EOB). The former shows decreased contents of REE, especially the heavy ones, and a slight positive Eu anomaly $\left(\mathrm{La}_{\mathrm{N}} / \mathrm{Sm}_{\mathrm{N}}=5.8, \mathrm{La}_{\mathrm{N}} / \mathrm{Yb}_{\mathrm{N}}=28.6, \mathrm{Eu} / \mathrm{Eu}^{*}=\right.$ $1.18, \Sigma R E E=76 \mathrm{ppm})$. The latter has a deep U shape, with markedly elevated $\operatorname{HREE}\left(\mathrm{La}_{\mathrm{N}} / \mathrm{Sm}_{\mathrm{N}}=14.1, \mathrm{La}_{\mathrm{N}} /\right.$ $\left.\mathrm{Yb}_{\mathrm{N}}=21.5, \mathrm{Eu} / \mathrm{Eu}^{*}=0.66, \Sigma \mathrm{REE}=141 \mathrm{ppm}\right)$. The REE patterns of the meta-rhyolites do not differ much from the 'normal' orthogneisses $\left(\mathrm{La}_{\mathrm{N}} / \mathrm{Sm}_{\mathrm{N}}=3.8-5.7, \mathrm{La}_{\mathrm{N}} / \mathrm{Yb}_{\mathrm{N}}\right.$ $=9.1-11.9, \mathrm{Eu} / \mathrm{Eu}^{*}=0.68-0.81, \Sigma \mathrm{REE}=136-219 \mathrm{ppm}$ ).

In accord with the HFSE depletion observed already in NMORB-normalized spiderplots, orthogneiss and metarhyolite samples fall within the Volcanic Arc Granite field of the tectonic discrimination diagrams by Pearce et al. (1984) (e.g., Fig. 11a) and to the Active Continental Margins field in $\mathrm{Yb}-\mathrm{Th} / \mathrm{Ta}$ plot by Schandl and Gorton (2002) (Fig. 11b).

\subsection{Whole-rock Nd isotopic composition}

Whole-rock Nd isotopic compositions were obtained in order to constrain the prospective source and crustal residence age of the protolith(s) to the studied metaigneous rocks. The new data, age-corrected to $375 \mathrm{Ma}$, are summarized in Tab. 6.

With a single exception of the sample V039a, the orthogneisses show mutually well comparable, positive $\varepsilon_{N d}^{375}$ values of +2.5 to +5.5 (Tab. 6; Fig. 12a). The two-stage Depleted-Mantle Nd model ages (Liew and Hofmann 1988) are also rather uniform $\left(T_{D M}^{N d}=0.64-0.89 \mathrm{Ga}\right)$ (Tab. 6). The two meta-rhyolites fall within the same intervals $\left(\varepsilon_{N d}^{375}\right.$ $=+3.1$ and $+3.5, T_{D M}^{N d}=0.81$ ad $0.84 \mathrm{Ga}$ ). However, a notable exception represents the NOB orthogneiss V039a with much less radiogenic neodymium $\left(\varepsilon_{N d}^{375}=-3.4, T_{D M}^{N d}=1.35 \mathrm{Ga}\right)$.

Taken together, the metaigneous rocks from the SOB, EOB and meta-rhyolites all give very homogeneous signal, with Neoproterozoic median $T_{D M}^{N d}$ close to $0.8 \mathrm{Ga}$ (Fig. 12a). The Northern Orthogneiss Belt, on the other hand, is significantly more variable.

Tab. 4 Trace-element whole-rock geochemical analyses (ppm)

\begin{tabular}{|c|c|c|c|c|c|c|c|c|c|c|c|}
\hline & V039a & V039b & V033 & P110 & V045 & D238 & D246 & D214 & D044 & V044 & D068 \\
\hline Region & NOB & NOB & NOB & SOB & SOB & EOB & EOB & EOB & $\mathrm{RB}$ & $\mathrm{RB}$ & $\mathrm{RB}$ \\
\hline $\mathrm{Rb}$ & 95 & 29 & 31 & 96 & 132 & 49 & 114 & 45 & 53 & 51 & 51 \\
\hline Cs & 1.7 & 0.8 & $<0.1$ & 2.0 & 2.4 & 1.6 & 2.0 & 0.3 & 0.3 & 0.1 & 0.6 \\
\hline $\mathrm{Ba}$ & 218 & 327 & 445 & 802 & 724 & 569 & 399 & 296 & 723 & 823 & 623 \\
\hline $\mathrm{Sr}$ & 91 & 446 & 173 & 431 & 386 & 249 & 98 & 115 & 134 & 159 & 119 \\
\hline $\mathrm{Be}$ & 2 & 1 & 2 & 2 & 2 & 2 & 2 & 2 & 2 & 2 & 2 \\
\hline $\mathrm{Ga}$ & 17 & 20 & 15 & 16 & 19 & 15 & 17 & 12 & 17 & 15 & 15 \\
\hline $\mathrm{Ge}$ & 1.5 & 0.8 & 1.5 & 1.6 & 2.0 & 1.5 & 1.4 & 1.3 & 1.8 & 1.6 & 1.4 \\
\hline Th & 7.46 & 3.35 & 10.30 & 14.30 & 24.60 & 12.30 & 14.80 & 24.60 & 10.80 & 8.32 & 11.30 \\
\hline $\mathrm{U}$ & 7.00 & 4.78 & 1.84 & 2.96 & 3.70 & 2.90 & 1.79 & 3.30 & 1.99 & 1.68 & 2.82 \\
\hline $\mathrm{Zr}$ & 154 & 130 & 196 & 235 & 246 & 192 & 122 & 86 & 252 & 217 & 169 \\
\hline Hf & 3.9 & 2.9 & 4.2 & 5.7 & 5.9 & 4.2 & 3.5 & 2.5 & 6.3 & 4.9 & 4.4 \\
\hline $\mathrm{Nb}$ & 10.7 & 5.2 & 15.3 & 12.7 & 15.8 & 13.8 & 18.8 & 14.7 & 19.5 & 11.9 & 17.3 \\
\hline $\mathrm{Ta}$ & 0.68 & 0.38 & 1.00 & 0.84 & 1.23 & 1.10 & 1.77 & 1.26 & 1.45 & 1.21 & 1.18 \\
\hline Sc & 13 & 4 & 4 & 7 & 5 & 4 & 3 & 2 & 5 & 4 & 2 \\
\hline $\mathrm{Cr}$ & 70 & $<20$ & $<20$ & $<20$ & $<20$ & 40 & $<20$ & 20 & $<20$ & $<20$ & $<20$ \\
\hline $\mathrm{Ni}$ & 50 & $<20$ & $<20$ & $<20$ & $<20$ & 740 & $<20$ & $<20$ & $<20$ & $<20$ & $<20$ \\
\hline Co & 14 & 5 & 2 & 6 & 4 & 53 & 2 & 2 & 1 & $<1$ & 2 \\
\hline $\mathrm{V}$ & 99 & 41 & 26 & 66 & 44 & 36 & 14 & 15 & 13 & 13 & 17 \\
\hline $\mathrm{Pb}$ & 10 & 8 & $<5$ & 8 & 13 & 5 & 19 & 5 & 9 & 10 & 7 \\
\hline $\mathrm{Zn}$ & 100 & 50 & $<30$ & $<30$ & 40 & $<30$ & 40 & $<30$ & 40 & $<30$ & 40 \\
\hline $\mathrm{Cu}$ & 30 & $<10$ & $<10$ & $<10$ & $<10$ & 10 & $<10$ & $<10$ & $<10$ & $<10$ & 20 \\
\hline Ag & 2.2 & 1.5 & 0.7 & 2.4 & 2 & 1.8 & 1.5 & 0.7 & 1.4 & 2.1 & 1.9 \\
\hline Sn & 2 & $<1$ & 1 & 2 & 2 & $<1$ & 2 & 1 & 3 & 2 & 2 \\
\hline W & 0.7 & 1.9 & $<0.5$ & 3.6 & 1.7 & 8.7 & 1.9 & 1.2 & $<0.5$ & 1.4 & 2.8 \\
\hline$\underline{\mathrm{Sb}}$ & 0.7 & 0.7 & $<0.2$ & 0.8 & 0.5 & 0.3 & 0.8 & $<0.2$ & $<0.2$ & 0.6 & 0.5 \\
\hline $\mathrm{Rb} / \mathrm{Sr}$ & 1.04 & 0.07 & 0.18 & 0.22 & 0.34 & 0.20 & 1.16 & 0.39 & 0.40 & 0.32 & 0.43 \\
\hline $\mathrm{Rb} / \mathrm{Ba}$ & 0.44 & 0.09 & 0.07 & 0.12 & 0.18 & 0.09 & 0.29 & 0.15 & 0.07 & 0.06 & 0.08 \\
\hline
\end{tabular}


Fig. 9 Trace-element signatures of the orthogneiss and metamorphosed rhyolite in NMORB-normalized spider plots (Sun and McDonough 1989). Individual patterns are colour-coded by the silica contents (wt. \%). The overall variability in the dataset is portrayed by the gray field.
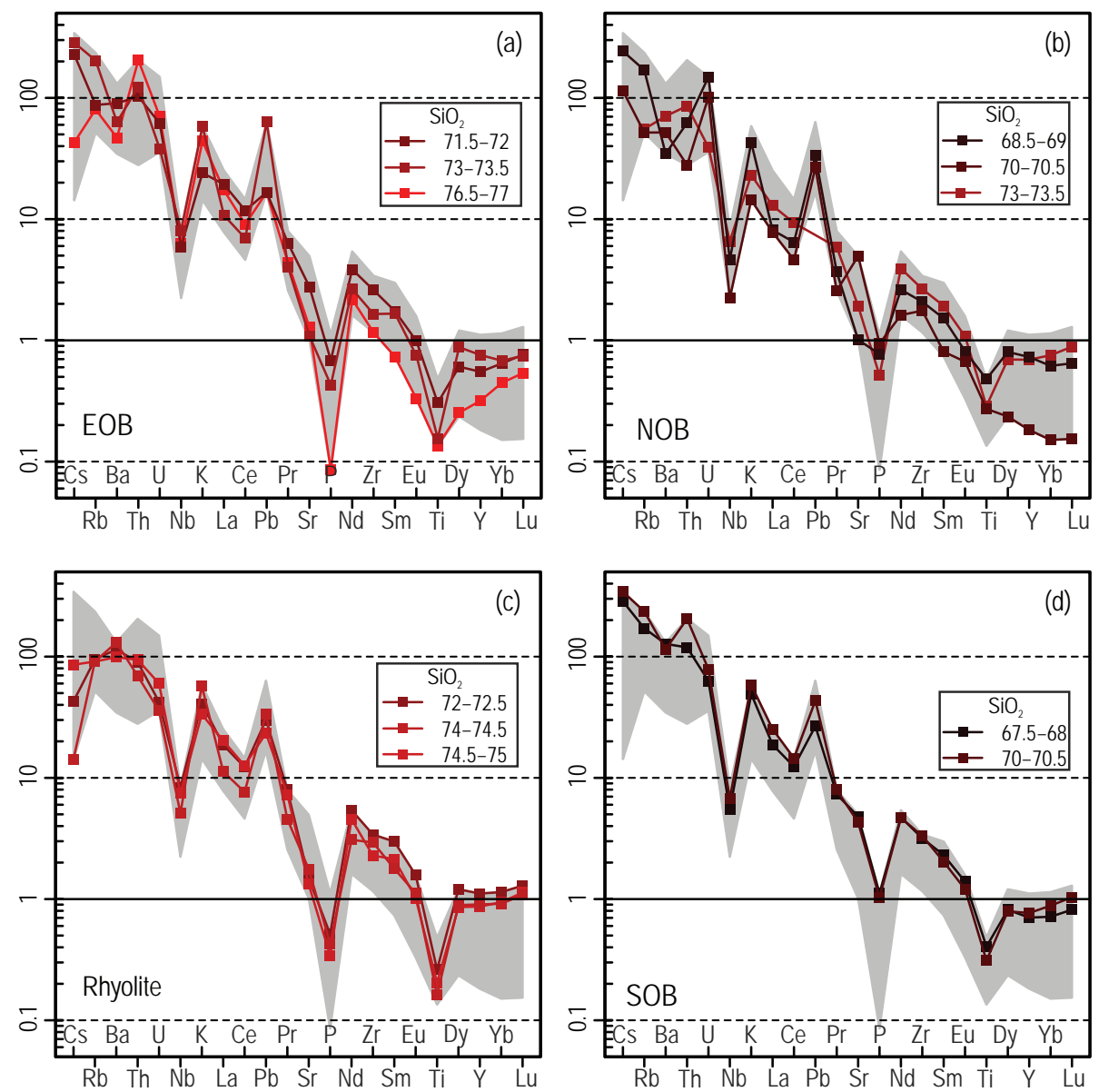

Tab. 5 Trace-element data, contd. (REE) (ppm)

\begin{tabular}{|c|c|c|c|c|c|c|c|c|c|c|c|}
\hline & V039a & V039b & V033 & P110 & V045 & D238 & D246 & D214 & D044 & V044 & D068 \\
\hline Region & NOB & NOB & NOB & SOB & SOB & EOB & EOB & EOB & $\mathrm{RB}$ & $\mathrm{RB}$ & $\mathrm{RB}$ \\
\hline $\mathrm{Y}$ & 20.4 & 5.1 & 19.4 & 19.7 & 21.5 & 15.4 & 21.2 & 8.9 & 31.1 & 25.3 & 24.3 \\
\hline $\mathrm{La}$ & 20.3 & 19.5 & 32.3 & 46.9 & 63.0 & 48.4 & 26.9 & 43.3 & 46.7 & 28.2 & 50.6 \\
\hline $\mathrm{Ce}$ & 48.4 & 34.6 & 69.8 & 92.9 & 109.0 & 88.4 & 52.1 & 68.0 & 91.8 & 57.3 & 94.6 \\
\hline $\operatorname{Pr}$ & 4.84 & 3.39 & 7.75 & 9.66 & 10.50 & 8.35 & 5.33 & 5.77 & 10.50 & 6.02 & 9.60 \\
\hline $\mathrm{Nd}$ & 19.1 & 11.8 & 28.6 & 34.5 & 34.1 & 28.1 & 19.3 & 15.9 & 39.5 & 22.5 & 33.3 \\
\hline $\mathrm{Sm}$ & 3.99 & 2.12 & 5.06 & 6.06 & 5.34 & 4.58 & 4.37 & 1.93 & 7.84 & 4.68 & 5.62 \\
\hline $\mathrm{Eu}$ & 0.83 & 0.68 & 1.10 & 1.42 & 1.23 & 1.01 & 0.76 & 0.34 & 1.61 & 1.14 & 1.04 \\
\hline Gd & 3.29 & 1.47 & 3.66 & 4.32 & 3.69 & 3.44 & 4.17 & 1.27 & 6.15 & 3.91 & 3.93 \\
\hline $\mathrm{Tb}$ & 0.55 & 0.21 & 0.55 & 0.64 & 0.58 & 0.48 & 0.70 & 0.17 & 0.98 & 0.65 & 0.62 \\
\hline Dy & 3.65 & 1.07 & 3.16 & 3.71 & 3.60 & 2.76 & 3.99 & 1.15 & 5.48 & 4.06 & 3.90 \\
\hline Ho & 0.71 & 0.18 & 0.63 & 0.73 & 0.75 & 0.56 & 0.78 & 0.26 & 1.10 & 0.86 & 0.83 \\
\hline Er & 2.02 & 0.49 & 1.94 & 2.14 & 2.34 & 1.68 & 2.16 & 0.90 & 3.23 & 2.56 & 2.61 \\
\hline $\mathrm{Tm}$ & 0.292 & 0.070 & 0.320 & 0.324 & 0.375 & 0.272 & 0.308 & 0.173 & 0.487 & 0.400 & 0.412 \\
\hline $\mathrm{Yb}$ & 1.88 & 0.46 & 2.30 & 2.18 & 2.69 & 1.97 & 2.07 & 1.36 & 3.48 & 2.79 & 2.87 \\
\hline $\mathrm{Lu}$ & 0.294 & 0.070 & 0.403 & 0.372 & 0.472 & 0.347 & 0.340 & 0.245 & 0.587 & 0.492 & 0.515 \\
\hline$\Sigma$ REE & 110.2 & 76.1 & 157.6 & 205.9 & 237.7 & 190.4 & 123.3 & 140.8 & 219.4 & 135.6 & 210.5 \\
\hline $\mathrm{La}_{\mathrm{N}} / \mathrm{Yb}_{\mathrm{N}}$ & 7.3 & 28.6 & 9.5 & 14.5 & 15.8 & 16.6 & 8.8 & 21.5 & 9.1 & 6.8 & 11.9 \\
\hline $\mathrm{La}_{\mathrm{N}} / \mathrm{Sm}_{\mathrm{N}}$ & 3.2 & 5.8 & 4.0 & 4.9 & 7.4 & 6.7 & 3.9 & 14.1 & 3.8 & 3.8 & 5.7 \\
\hline $\mathrm{Eu} / \mathrm{Eu}^{*}$ & 0.70 & 1.18 & 0.78 & 0.85 & 0.85 & 0.78 & 0.55 & 0.66 & 0.71 & 0.81 & 0.68 \\
\hline $\mathrm{Yb}_{\mathrm{N}}$ & 9.0 & 2.2 & 11.0 & 10.4 & 12.9 & 9.4 & 9.9 & 6.5 & 16.7 & 13.4 & 13.7 \\
\hline
\end{tabular}



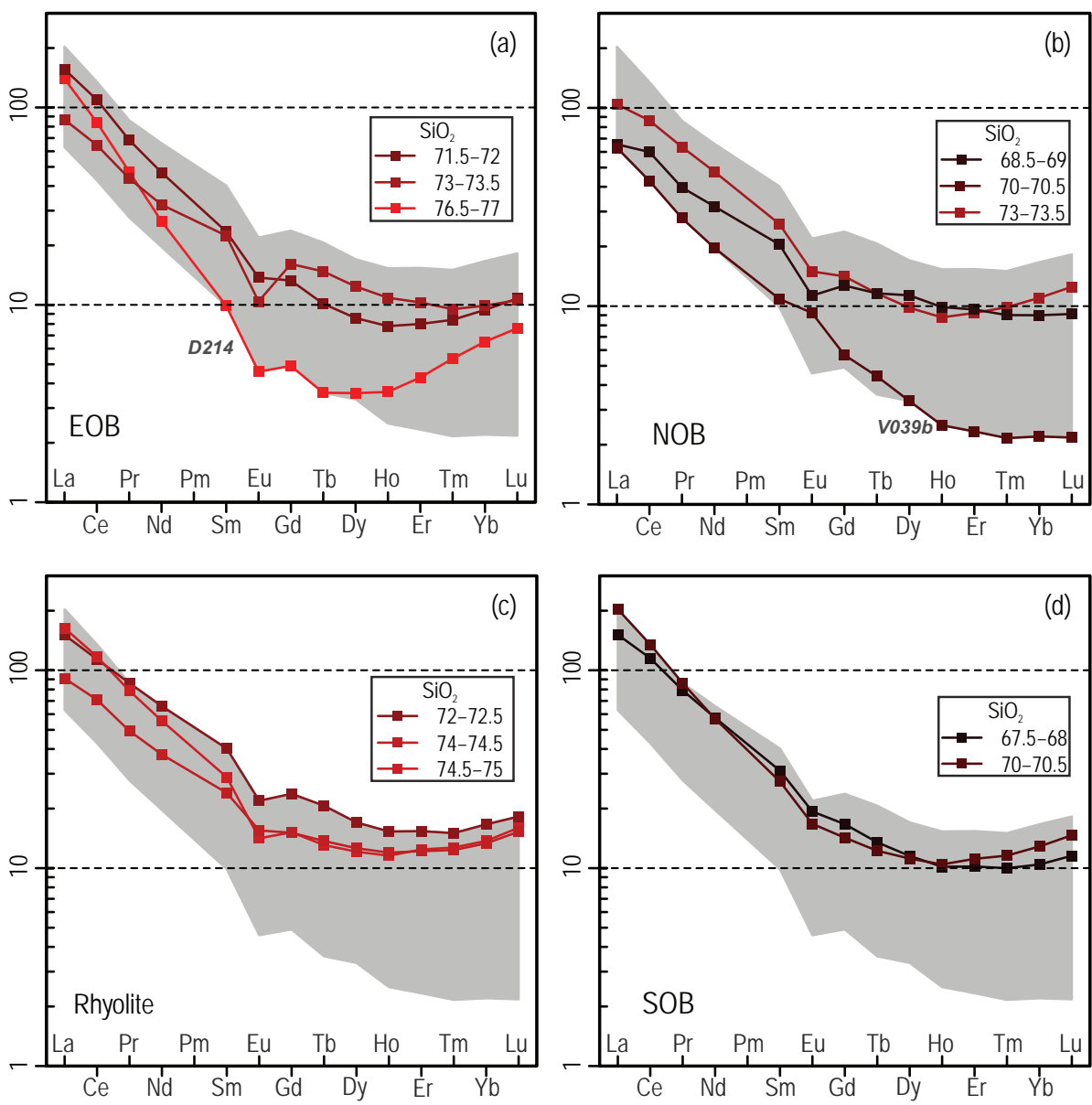

Fig. 10 Chondrite-normalized REE patterns (Boynton 1984) colour-coded by the silica contents (wt. \%)

\subsection{U-Pb zircon dating and in situ Hf isotope composition}

\subsubsection{Augen orthogneisses of the Southern Orthogneiss Belt (samples Y068 and K132)}

Zircon grains of the sample $\mathbf{Y 0 6 8}$ are dominated by euhedral prisms, ranging in length from 100 to $200 \mu \mathrm{m}$, with an average length/width ratio of $2: 1$. Cores are clear, with distinct oscillatory zoning and strong CL contrast in a 30-40 $\mu \mathrm{m}$ wide outer mantle suggesting their igneous origin. Nine grains from sample Y068 form a cluster of concordant points, with a weighted mean ${ }^{206} \mathrm{~Pb} /{ }^{238} \mathrm{U}$ age of $373 \pm 3 \mathrm{Ma}$ (Tab. 7, Fig. 13a). Two show older ages of $431 \pm 12 \mathrm{Ma}$ and $508 \pm 15 \mathrm{Ma}$ respectively.

Zircons for sample K132 range in length from 100 to $300 \mu \mathrm{m}$ with an average length/width ratio of $2: 1$ to $3: 1$. Clear cores are relatively small (about $40 \mu \mathrm{m}$ ) and pass early into oscillatory-zoned outer mantle. Zoning is locally irregular or accompanied by zones or spots of strikingly high luminescence. Some grains contain darker domains and spots that arose most likely due to different growth ratios and were cogenetic to the mantle part and not to an older core. Eight grains

Fig. 11 Geotectonic discrimination diagrams. a - Yb-Ta of Pearce et al. (1984); ORG = Ocean Ridge Granites, VAG $=$ Volcanic Arc Granites, WPG $=$ Within Plate Granites, syn-COLG $=$ syn-Collision Granites. b - Yb vs. Th/ Ta of Schandl and Gorton (2002). 
Fig. 12 The Nd-Hf isotopic signatures for the studied metaigneous samples. a - Two-stage Nd development diagram. The extra tick marks on the ordinate indicate the initial $\varepsilon_{\mathrm{Nd}}$ values, on the abscissa the two-stage DepletedMantle Nd model ages (after Liew and Hofmann 1988). DM = Depleted Mantle evolution lines after [1]: Goldstein et al. (1984) and [2]: Liew and Hofmann (1988). Inset: Boxplot of two-stage Depleted-Mantle Nd model ages $\left(T_{D M}^{N d}\right)$. b - Hafnium development diagram for the dated zircons. The extra tick marks on the ordinate indicate the $\varepsilon_{H f}^{t}$ values, on the abscissa the DepletedMantle Hf model ages $\left(T_{D M}^{C}\right)$. Inset: Boxplot of "crustal" Hf model ages $\left(T_{D M}^{C}\right)$ from the same samples.

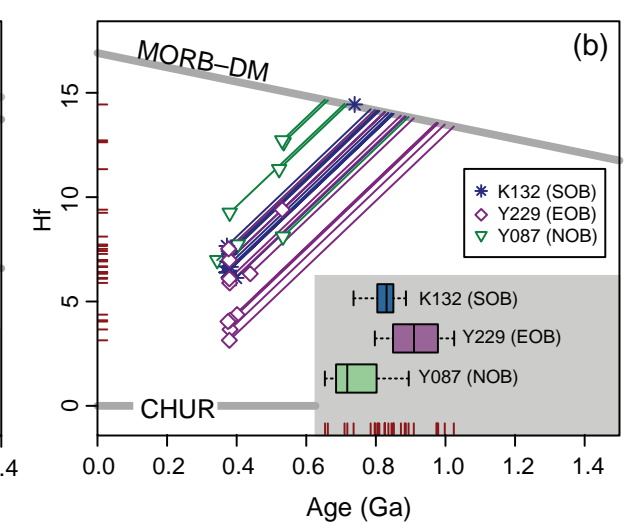

from sample K132 gave a weighted mean ${ }^{206} \mathrm{~Pb} /{ }^{238} \mathrm{U}$ age of $377 \pm 5 \mathrm{Ma}$; distinctly older age of $739 \pm 23$ Ma was obtained from one grain (Tab 7, Fig. 13b).

Taken together, the zircon ages from two samples of the SOB provided consistent set of geochronological data. The ages of $373 \pm 3 \mathrm{Ma}$ and $377 \pm 5 \mathrm{Ma}$ are interpreted as crystallization ages of the parental granitic magma. The older ages of 398, 432, 508 and $739 \mathrm{Ma}$ (Tab. 7) represent most likely xenocrysts from the country rocks.

Because both specimens come from the same unit, only zircons from sample K132 have been analyzed for Lu-Hf isotopic composition. The $c$. 375 Ma zircons show a tight cluster of $\varepsilon_{H f}^{t}$ values ranging from +6.1 to +7.7 , with $T_{D M}^{C}$ model ages of $0.77-0.87 \mathrm{Ga}$. One $c$. $739 \mathrm{Ma}$ xenocryst yielded a $\varepsilon_{H f}^{t}$ value of +14.4 with $T_{D M}^{C}$ model age of $0.74 \mathrm{Ga}$ (Fig. 12b, Tab. 8).

\subsubsection{Orthogneiss of the Eastern Orthogneiss Belt (Y229)}

Zircons from the sample Y229 are subhedral to anhedral, variably corroded, of originally equant shape. Their CL imagery reveals indistinctive sector zoning with locally preserved oscillatory zoning. Most of zircons display only a weak luminescence.

Thirteen grains were selected for isotopic analysis. Seven of them form a cluster of concordant points with a weighted mean ${ }^{206} \mathrm{~Pb} /{ }^{238} \mathrm{U}$ age of $379 \pm 2 \mathrm{Ma}$ (Fig 13c), which, most likely, represents the crystallization of the orthogneiss protolith. Analysis of two additional grains yielded concordant ages of $439 \pm 2$ and $531 \pm 6 \mathrm{Ma}$, respectively. These grains are interpreted as xenocrysts derived from the country rocks. Four analyses yielded discordant ages, probably due to Pb-loss, and these are not further discussed here.

The $\varepsilon_{H f}^{t}$ values for most of the zircon population vary from +3.1 to +7.5 , with $T_{D M}^{C}$ model ages of $0.78-1.00 \mathrm{Ga}$. The two xenocrystic zircons yielded $\varepsilon_{H f}^{t}$ values of +6.3 and +9.4 , with corresponding $T_{D M}^{C}$ model ages of $0.89 \mathrm{Ga}$ and $0.82 \mathrm{Ga}$, respectively (Fig. 12b, Tab. 8).

\subsubsection{Meta-rhyolite of the Northern Orthogneiss Belt (Y087)}

Meta-rhyolite Y087 provided very variable set of zircons; subhedral prismatic grains up to $200 \mu \mathrm{m}$ long with

Tab. 6 Whole-rock Nd isotopic data

\begin{tabular}{|c|c|c|c|c|c|c|c|c|c|c|}
\hline Sample & Belt & $\begin{array}{c}\mathrm{SiO}_{2} \\
\text { (wt. \%) }\end{array}$ & $\begin{array}{c}\mathrm{Sm} \\
(\mathrm{ppm})\end{array}$ & $\begin{array}{c}\mathrm{Nd} \\
(\mathrm{ppm})\end{array}$ & ${ }^{147} \mathrm{Sm} /{ }^{144} \mathrm{Nd}$ & ${ }^{143} \mathrm{Nd} /{ }^{144} \mathrm{Nd}$ & $2 \mathrm{se}^{1}$ & $\left({ }^{143} \mathrm{Nd} /{ }^{144} \mathrm{Nd}\right)_{375}{ }^{2}$ & $\varepsilon_{N d}^{375}$ & $T_{D M}^{N d 3}$ \\
\hline P110 & SOB & 67.62 & 6.06 & 34.5 & 0.1062 & 0.512542 & 0.000028 & 0.512281 & +2.5 & 0.89 \\
\hline V045 & SOB & 70.19 & 5.34 & 34.1 & 0.0947 & 0.512593 & 0.000014 & 0.512361 & +4.0 & 0.76 \\
\hline D246 & EOB & 73.46 & 4.37 & 19.3 & 0.1369 & 0.512700 & 0.000008 & 0.512364 & +4.1 & 0.76 \\
\hline D214 & EOB & 76.95 & 1.93 & 15.9 & 0.0734 & 0.512554 & 0.000017 & 0.512374 & +4.3 & 0.74 \\
\hline V039a & NOB & 68.61 & 3.99 & 19.1 & 0.1263 & 0.512291 & 0.000015 & 0.511981 & -3.4 & 1.35 \\
\hline V033 & NOB & 73.03 & 5.06 & 28.6 & 0.1070 & 0.512701 & 0.000016 & 0.512438 & +5.5 & 0.64 \\
\hline D044 & rhyolite & 72.25 & 7.84 & 39.5 & 0.1200 & 0.512628 & 0.000007 & 0.512333 & +3.5 & 0.81 \\
\hline V044 & rhyolite & 74.12 & 4.68 & 22.5 & 0.1258 & 0.512620 & 0.000013 & 0.512311 & +3.1 & 0.84 \\
\hline
\end{tabular}

${ }^{1} 2$ standard errors of the mean

${ }^{2}$ subscripts ' 375 ' indicate age-corrected isotopic ratios

${ }^{3}$ two-stage Nd model ages (Ga) (Liew and Hofmann 1988) 
Tab. 7 Laser-ablation ICP-MS U-Pb data for zircons from meta-igneous rocks of the eastern Tseel Metamorphic Complex

\begin{tabular}{|c|c|c|c|c|c|c|c|c|c|c|c|c|c|c|}
\hline \multirow{2}{*}{ Sample } & \multirow{2}{*}{ Spot } & \multicolumn{6}{|c|}{ Isotope ratios and errors } & \multicolumn{6}{|c|}{ Ages (Ma) } & \multirow{2}{*}{$\begin{array}{c}\text { Weighted } \\
\text { mean }\end{array}$} \\
\hline & & ${ }^{207} \mathrm{~Pb} /{ }^{206} \mathrm{~Pb}$ & $1 \sigma$ & ${ }^{207} \mathbf{P b} /{ }^{235} \mathbf{U}$ & $1 \sigma$ & ${ }^{206} \mathbf{P b} /{ }^{238} \mathrm{U}$ & $1 \sigma$ & ${ }^{207} \mathrm{~Pb} /{ }^{206} \mathrm{~Pb}$ & $1 \sigma$ & ${ }^{207} \mathbf{P b} /{ }^{235} \mathbf{U}$ & $1 \sigma$ & ${ }^{206} \mathrm{~Pb} /{ }^{238} \mathrm{U}$ & $1 \sigma$ & \\
\hline Y068 & 1 & 0.055004 & 0.006167 & 0.532803 & 0.029879 & 0.069071 & 0.001931 & 412 & 76 & 434 & 20 & 431 & 12 & $373 \pm 3$ \\
\hline Y068 & 2 & 0.056764 & 0.005667 & 0.630856 & 0.029750 & 0.082046 & 0.002528 & 482 & 53 & 497 & 19 & 508 & 15 & \\
\hline Y068 & 3 & 0.051218 & 0.005352 & 0.416004 & 0.020306 & 0.059764 & 0.001748 & 251 & 61 & 353 & 15 & 374 & 11 & \\
\hline Y068 & 5 & 0.054071 & 0.004843 & 0.458874 & 0.019672 & 0.060414 & 0.001875 & 374 & 46 & 383 & 14 & 378 & 11 & \\
\hline Y068 & 6 & 0.053389 & 0.009131 & 0.427720 & 0.027896 & 0.060238 & 0.003017 & 345 & 69 & 362 & 20 & 377 & 18 & \\
\hline Y068 & 7 & 0.055808 & 0.004884 & 0.452166 & 0.019193 & 0.059087 & 0.001742 & 445 & 47 & 379 & 13 & 370 & 11 & \\
\hline Y068 & 8 & 0.054633 & 0.003606 & 0.450553 & 0.014172 & 0.059118 & 0.001572 & 397 & 32 & 378 & 10 & 370 & 10 & \\
\hline Y068 & 9 & 0.052665 & 0.003255 & 0.444547 & 0.014747 & 0.059188 & 0.001337 & 314 & 38 & 373 & 10 & 371 & 8 & \\
\hline Y068 & 11 & 0.054558 & 0.003768 & 0.447569 & 0.015119 & 0.059068 & 0.001138 & 394 & 42 & 376 & 11 & 370 & 7 & \\
\hline Y068 & 12 & 0.054831 & 0.003584 & 0.452151 & 0.014853 & 0.059842 & 0.001400 & 405 & 36 & 379 & 10 & 375 & 9 & \\
\hline Y068 & 14 & 0.052987 & 0.003172 & 0.455896 & 0.016441 & 0.059294 & 0.001369 & 328 & 42 & 381 & 11 & 371 & 8 & \\
\hline K132 & 1 & 0.054120 & 0.002980 & 0.441360 & 0.012270 & 0.059460 & 0.000960 & 376 & 35 & 371 & 9 & 372 & 6 & $377 \pm 5$ \\
\hline K132 & 2 & 0.055390 & 0.003860 & 0.450930 & 0.014650 & 0.059480 & 0.001460 & 428 & 34 & 378 & 10 & 372 & 9 & \\
\hline K132 & 3 & 0.052930 & 0.003760 & 0.442030 & 0.014340 & 0.060580 & 0.001140 & 326 & 41 & 372 & 10 & 379 & 7 & \\
\hline K132 & 4 & 0.051660 & 0.003240 & 0.442440 & 0.014170 & 0.059430 & 0.001460 & 270 & 34 & 372 & 10 & 372 & 9 & \\
\hline K132 & 5 & 0.064930 & 0.008040 & 1.055030 & 0.056360 & 0.121480 & 0.004020 & 772 & 60 & 731 & 28 & 739 & 23 & \\
\hline K132 & 6 & 0.050510 & 0.006680 & 0.462720 & 0.032190 & 0.061100 & 0.002210 & 219 & 95 & 386 & 22 & 382 & 13 & \\
\hline K132 & 7 & 0.054470 & 0.006580 & 0.481130 & 0.022950 & 0.063730 & 0.001610 & 391 & 63 & 399 & 16 & 398 & 10 & \\
\hline K132 & 8 & 0.052670 & 0.007860 & 0.455490 & 0.034570 & 0.059750 & 0.001250 & 315 & 135 & 381 & 24 & 374 & 8 & \\
\hline K132 & 13 & 0.054840 & 0.003510 & 0.451810 & 0.013770 & 0.059470 & 0.001250 & 406 & 34 & 379 & 10 & 372 & 8 & \\
\hline K132 & 15 & 0.052590 & 0.003010 & 0.451170 & 0.013380 & 0.060550 & 0.001020 & 311 & 38 & 378 & 9 & 379 & 6 & \\
\hline Y229 & 1 & 0.056282 & 0.000234 & 0.546487 & 0.003923 & 0.070414 & 0.000393 & 465 & 9 & 443 & 3 & 439 & 2 & $379 \pm 2$ \\
\hline Y229 & 2 & 0.056466 & 0.000242 & 0.499224 & 0.005000 & 0.064110 & 0.000546 & 472 & 9 & 411 & 3 & 401 & 3 & \\
\hline Y229 & 3 & 0.054709 & 0.000173 & 0.459077 & 0.004270 & 0.060927 & 0.000585 & 467 & 6 & 384 & 3 & 381 & 4 & \\
\hline Y229 & 4 & 0.058415 & 0.000218 & 0.690862 & 0.007508 & 0.085844 & 0.000955 & 546 & 7 & 533 & 5 & 531 & 6 & \\
\hline Y229 & 5 & 0.055251 & 0.000556 & 0.461668 & 0.005940 & 0.060585 & 0.000326 & 433 & 29 & 385 & 4 & 379 & 2 & \\
\hline Y229 & 8 & 0.055020 & 0.000260 & 0.460860 & 0.005300 & 0.060720 & 0.000620 & 413 & 11 & 385 & 4 & 380 & 4 & \\
\hline Y229 & 9 & 0.055762 & 0.000296 & 0.467675 & 0.004197 & 0.060812 & 0.000412 & 443 & 11 & 390 & 3 & 381 & 3 & \\
\hline Y229 & 12 & 0.062330 & 0.000702 & 0.521221 & 0.012267 & 0.060510 & 0.000808 & 687 & 24 & 426 & 8 & 379 & 5 & \\
\hline Y229 & 13 & 0.055963 & 0.000503 & 0.467597 & 0.005765 & 0.060601 & 0.000540 & 450 & 20 & 390 & 4 & 379 & 3 & \\
\hline Y229 & 14 & 0.061464 & 0.000494 & 0.510382 & 0.006094 & 0.060188 & 0.000341 & 655 & 17 & 419 & 4 & 377 & 2 & \\
\hline Y229 & 15 & 0.056377 & 0.000908 & 0.465734 & 0.005543 & 0.059925 & 0.000481 & 478 & 35 & 388 & 4 & 375 & 3 & \\
\hline Y229 & 16 & 0.064929 & 0.000410 & 0.539077 & 0.007468 & 0.060104 & 0.000537 & 772 & 10 & 438 & 5 & 376 & 3 & \\
\hline Y229 & 20 & 0.068221 & 0.000366 & 0.565030 & 0.006382 & 0.060049 & 0.000591 & 876 & 11 & 455 & 4 & 376 & 4 & \\
\hline $\begin{array}{l}\text { Y087 } \\
\end{array}$ & 1 & 0.057848 & 0.000600 & 0.673121 & 0.009411 & 0.084361 & 0.000913 & 524 & 78 & 523 & 6 & 522 & 5 & $530 \pm 6$ \\
\hline Y087 & 3 & 0.058951 & 0.000747 & 0.703226 & 0.011051 & 0.086455 & 0.000870 & 565 & 39 & 541 & 7 & 535 & 5 & \\
\hline Y087 & 5 & 0.054816 & 0.000508 & 0.487358 & 0.006797 & 0.064504 & 0.000808 & 406 & 22 & 403 & 5 & 403 & 5 & \\
\hline Y087 & 6 & 0.054826 & 0.000500 & 0.458530 & 0.006026 & 0.060669 & 0.000717 & 406 & 22 & 383 & 4 & 380 & 4 & \\
\hline Y087 & 7 & 0.057921 & 0.000465 & 0.686918 & 0.011308 & 0.085923 & 0.001209 & 528 & 83 & 531 & 7 & 531 & 7 & \\
\hline Y087 & 8 & 0.059692 & 0.000226 & 0.709058 & 0.011554 & 0.086114 & 0.001450 & 591 & 11 & 544 & 7 & 533 & 9 & \\
\hline Y087 & 9 & 0.059873 & 0.000914 & 0.670675 & 0.013430 & 0.081174 & 0.000968 & 598 & 33 & 521 & 8 & 503 & 6 & \\
\hline Y087 & 10 & 0.055260 & 0.000790 & 0.417999 & 0.006668 & 0.054829 & 0.000519 & 433 & 33 & 355 & 5 & 344 & 3 & \\
\hline
\end{tabular}

aspect ratio $1: 3$, equant/short prismatic grains $100-150$ $\mu \mathrm{m}$ across and grain fragments. The first type - long prismatic zircons - displays distinct sector zoning with strong CL contrast; smaller and short prismatic grains show sector or oscillatory zoning.

Eight analyses of the oscillatory-zoned grains were conducted. Two of them yielded concordant ages of $380 \pm 4$ and $403 \pm 5 \mathrm{Ma}$, respectively. Four analyses form a cluster of concordant points with a weighted mean ${ }^{206} \mathrm{~Pb} /{ }^{238} \mathrm{U}$ age of $530 \pm 6 \mathrm{Ma}$ (Fig. 13d). Further two analyses yielded discordant ages. The concordant ages of $c$. 380 and $400 \mathrm{Ma}$ are taken as the best estimates of the crystallization of the rhyolitic magma. The c. 530 Ma zircons were interpreted as xenocrysts possibly inherited from the host Tugrug Fm. The discordant analyses are taken as consequence of a metamorphic disturbance.

The 380 and 403 Ma zircons gave $\varepsilon_{H f}^{t}$ values of +9.2 and +7.7 with $T_{D M}^{C}$ model ages of 0.70 and $0.79 \mathrm{Ga}$, respectively. The xenocrysts gave $\varepsilon_{H f}^{t}$ values ranging from 
Fig. 13 Zircon U-Pb concordia plots for the studied orthogneisses and metarhyolite. Inset: typical CL photographs (white scale bar is always $100 \mu \mathrm{m}$ long).
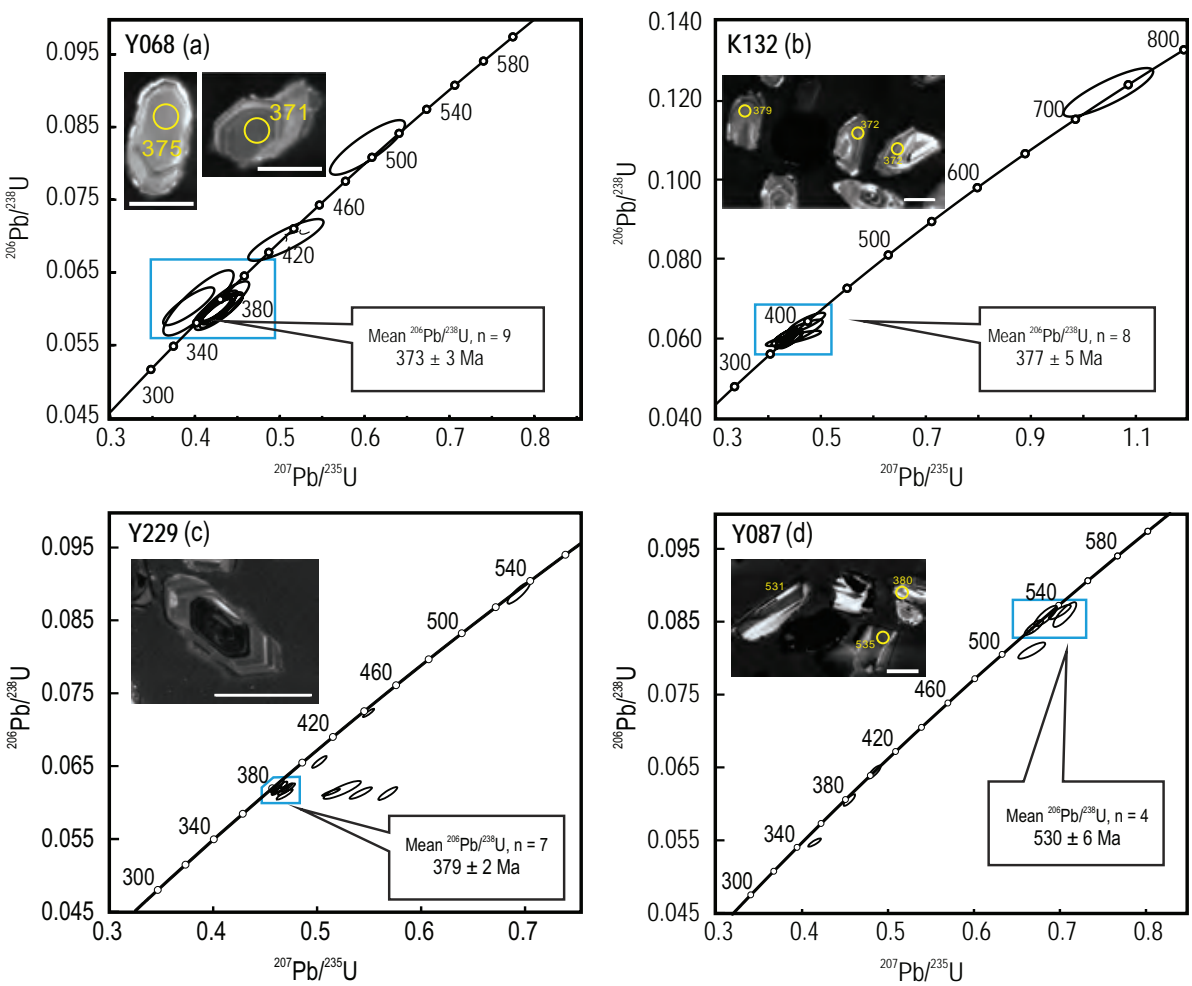

Tab. 8 In situ Hf analytical data for dated zircons

\begin{tabular}{|c|c|c|c|c|c|c|c|c|c|c|c|}
\hline No & ${ }^{176} \mathrm{Hf} /{ }^{177} \mathrm{Hf}$ & $\pm(2 \sigma)$ & ${ }^{176} \mathrm{Lu} /{ }^{177} \mathbf{H f}$ & $\pm(2 \sigma)$ & ${ }^{176} \mathbf{Y b} /{ }^{177} \mathbf{H f}$ & $\pm(2 \sigma)$ & Age (Ma) & $\left.{ }^{(176} \mathrm{Hf} /{ }^{177} \mathrm{Hf}\right)_{\mathrm{t}}$ & $\varepsilon_{H f}^{t}$ & $T_{D M}^{C}(\mathrm{Ga})$ & $2 \sigma$ \\
\hline K132-1 & 0.28274 & 0.00002 & 0.00195 & 0.00001 & 0.05722 & 0.00038 & 372 & 0.28273 & 6.7 & 0.82 & 0.06 \\
\hline K132-2 & 0.28276 & 0.00002 & 0.00101 & 0.00001 & 0.02939 & 0.00017 & 372 & 0.28276 & 7.7 & 0.77 & 0.06 \\
\hline K132-3 & 0.28275 & 0.00002 & 0.00113 & 0.00001 & 0.02855 & 0.00029 & 379 & 0.28274 & 7.3 & 0.79 & 0.06 \\
\hline K132-4 & 0.28273 & 0.00002 & 0.00098 & 0.00001 & 0.02764 & 0.00021 & 372 & 0.28272 & 6.4 & 0.83 & 0.06 \\
\hline K132-5 & 0.28275 & 0.00002 & 0.00207 & 0.00007 & 0.06621 & 0.00218 & 739 & 0.28272 & 14.4 & 0.74 & 0.06 \\
\hline K132-6 & 0.28273 & 0.00002 & 0.00104 & 0.00001 & 0.02881 & 0.00025 & 382 & 0.28272 & 6.7 & 0.83 & 0.06 \\
\hline K132-7 & 0.28272 & 0.00003 & 0.00261 & 0.00005 & 0.07497 & 0.00219 & 398 & 0.28270 & 6.1 & 0.87 & 0.06 \\
\hline K132-8 & 0.28275 & 0.00002 & 0.00174 & 0.00007 & 0.05253 & 0.00215 & 374 & 0.28273 & 6.9 & 0.81 & 0.06 \\
\hline K132-13 & 0.28274 & 0.00002 & 0.00253 & 0.00008 & 0.07461 & 0.00223 & 372 & 0.28272 & 6.4 & 0.83 & 0.06 \\
\hline K132-15 & 0.28275 & 0.00002 & 0.00116 & 0.00001 & 0.03457 & 0.00058 & 379 & 0.28275 & 7.4 & 0.79 & 0.06 \\
\hline Y229-1 & 0.28269 & 0.00002 & 0.00200 & 0.00003 & 0.07007 & 0.00108 & 439 & 0.28268 & 6.3 & 0.89 & 0.06 \\
\hline Y229-2 & 0.28266 & 0.00002 & 0.00134 & 0.00002 & 0.03867 & 0.00086 & 401 & 0.28265 & 4.4 & 0.96 & 0.06 \\
\hline Y229-3 & 0.28265 & 0.00003 & 0.00147 & 0.00006 & 0.04139 & 0.00100 & 381 & 0.28264 & 3.7 & 0.98 & 0.06 \\
\hline Y229-4 & 0.28272 & 0.00002 & 0.00172 & 0.00004 & 0.05445 & 0.00122 & 531 & 0.28271 & 9.4 & 0.82 & 0.06 \\
\hline Y229-5 & 0.28265 & 0.00002 & 0.00354 & 0.00011 & 0.12711 & 0.00428 & 379 & 0.28263 & 3.1 & 1.00 & 0.06 \\
\hline Y229-8 & 0.28271 & 0.00002 & 0.00125 & 0.00007 & 0.03554 & 0.00113 & 380 & 0.28270 & 5.9 & 0.86 & 0.06 \\
\hline Y229-9 & 0.28267 & 0.00003 & 0.00312 & 0.00005 & 0.09503 & 0.00121 & 381 & 0.28265 & 4.1 & 0.95 & 0.06 \\
\hline Y229-12 & 0.28272 & 0.00002 & 0.00123 & 0.00001 & 0.03777 & 0.00050 & 379 & 0.28271 & 6.1 & 0.85 & 0.06 \\
\hline Y229-13 & 0.28274 & 0.00002 & 0.00104 & 0.00001 & 0.03431 & 0.00034 & 379 & 0.28273 & 7.0 & 0.81 & 0.06 \\
\hline Y229-14 & 0.28276 & 0.00002 & 0.00101 & 0.00001 & 0.03333 & 0.00062 & 377 & 0.28275 & 7.5 & 0.78 & 0.06 \\
\hline Y229-15 & 0.28266 & 0.00003 & 0.00087 & 0.00003 & 0.02457 & 0.00047 & 375 & 0.28265 & 4.0 & 0.95 & 0.06 \\
\hline Y087-1 & 0.28277 & 0.00002 & 0.00060 & 0.00000 & 0.01467 & 0.00006 & 522 & 0.28277 & 11.3 & 0.71 & 0.06 \\
\hline Y087-3 & 0.28280 & 0.00003 & 0.00084 & 0.00002 & 0.02034 & 0.00043 & 535 & 0.28280 & 12.6 & 0.66 & 0.06 \\
\hline Y087-4 & 0.28280 & 0.00002 & 0.00015 & 0.00000 & 0.00266 & 0.00003 & 380 & 0.28280 & 9.2 & 0.70 & 0.06 \\
\hline Y087-5 & 0.28275 & 0.00003 & 0.00164 & 0.00001 & 0.03815 & 0.00027 & 403 & 0.28274 & 7.7 & 0.79 & 0.06 \\
\hline Y087-7 & 0.28280 & 0.00002 & 0.00046 & 0.00001 & 0.01111 & 0.00020 & 531 & 0.28280 & 12.7 & 0.65 & 0.06 \\
\hline Y087-8 & 0.28270 & 0.00004 & 0.00280 & 0.00007 & 0.05374 & 0.00131 & 533 & 0.28267 & 8.1 & 0.88 & 0.06 \\
\hline Y087-10 & 0.28276 & 0.00002 & 0.00152 & 0.00002 & 0.03469 & 0.00044 & 344 & 0.28275 & 7.0 & 0.78 & 0.06 \\
\hline
\end{tabular}


+8.1 to +12.7 , with calculated $T_{D M}^{C}$ model ages varying between $0.65 \mathrm{Ga}$ and $0.88 \mathrm{Ga}$ (Fig. 12b, Tab. 8).

\section{Discussion}

The main questions arising during the current study have been: 1) Which deformation event transformed granitoids to orthogneisses? 2) Did the crust of Mongolian Altai represent an old continental crustal segment or rather a young type of crust with structure typical of accretionary systems? The former issue was addressed by structural analysis, the latter by geochronology and whole-rock geochemistry. Altogether the new data constrain origin of these spectacular orthogneiss bodies, which, as we believe, provide insight into the question of possible existence of basement underlying the Mongolian Altai.

\subsection{Deformation and metamorphism of Mongolian Altai granitoids at different crustal levels}

Geological relationships and structural analysis of orthogneisses, meta-rhyolites and host-rock metasediments reveal a complex polyphase history which can be summarized as follows. 1) All units show, at least in relics, sub-horizontal metamorphic schistosity $\mathrm{S}_{2}$ overprinting bedding in low-grade pre-Carboniferous units or $\mathrm{S}_{1}$ foliation in higher grade infrastructure. 2) This principal fabric is associated with recumbent mesoscopic folds with variable orientation of fold hinges. 3) All previous were refolded by upright $\mathrm{F}_{3}$ folds with horizontal NWSE trending hinges. 4) Carboniferous sequences do not reveal presence of neither metamorphic schistosity $S_{1}$ and $\mathrm{S}_{2}$ nor recumbent folds $\mathrm{F}_{2}$.

Various field observations document (Fig. 5) that the foliation $S_{1}$ was at high angle to $S_{2}$ implying originally steep attitude prior to the $\mathrm{D}_{2}$ deformation. In contrast, restoration of $\mathrm{S}_{2}$ foliation and $\mathrm{F}_{2}$ folds into pre- $\mathrm{D}_{3}$ position indicates that $\mathrm{S}_{2}$ was sub-horizontal and $\mathrm{F}_{2}, \mathrm{~L}_{2}$ oriented generally in $\mathrm{N}-\mathrm{NE}$ direction. Field observations suggest that the intensity of sub-horizontal metamorphic fabric and recumbent folding increases with the depth where felsic gneisses, tonalites, gabbros and amphibolites show effects of pervasive $\mathrm{D}_{2}$ deformation. In contrast, the $\mathrm{D}_{2}$ deformation is heterogeneous in the Devonian sediments. The degree of $\mathrm{D}_{3}$ deformation significantly increases towards the boundaries of HGI and MGI domains. In particular, $\mathrm{D}_{3}$ forms wide zone of intense sub-vertical greenschist-facies mylonitic fabric at the SLG and MGI boundary. It is very weak in the SLG and in most of the MGI and HGI.

Protolith to the orthogneiss in Tseel Terrane could represent granitoids of Cambrian to Devonian ages (Jiang et al. 2012; Burenjargal et al. 2014). Our study shows that these bodies were transposed, gneissified and metamorphosed together with surrounding metasediments and amphibolites and could have been pre- or syn-tectonic with the main $\mathrm{D}_{2}$ Devonian metamorphic event which can be attributed to horizontal flow of deep crust (Broussole et al. 2015; Jiang et al. 2015; Zhang et al. 2015). Lack of $\mathrm{D}_{1-2}$ fabrics in the Carboniferous volcanosedimentary series implies that these basins originated syn- to posttectonically with this event. When affected by late $D_{3}$ deformation, the whole rock package was significantly horizontally shortened. This late deformation most likely resulted from Permian NE-SW horizontal shortening which reworked heterogeneously the whole region of Mongolian Altai (Lehmann et al. 2010; Guy et al. 2014b).

The layered horizontal architecture of studied area is typical of continental crust dominated by felsic gneiss sheeted bodies interlayered with packages of metasediments. It can originate either by imbrication of basement thrust sheets in both compressional and extensional settings or by sill-like intrusions of syntectonic granitoids parallel to horizontal anisotropy. However, as is often the case, the structural analysis alone cannot provide convincing interpretation of complex magmatic and metamorphic history of orogenic belts and other tools are needed to provide a plausible model of crustal growth mechanisms. It is in particular high-resolution geochronology and whole-rock geochemistry, which can yield robust information supporting geological models thereby allowing grasping even most complex crustal growth scenarios.

\subsection{Age and character of the protolith to the orthogneisses}

Two samples of coarse-grained orthogneiss exposed along the southern rim of the Tseel Complex yield consistent Late Devonian (Frasnian) ages of $373 \pm 3$ and $377 \pm 5 \mathrm{Ma}$. They are, together with the age of $379 \pm 2$ Ma for finegrained orthogneiss from the Eastern Orthogneiss Belt, interpreted to date crystallization of zircons from a granodioritic-tonalitic magma. All three ages are in good accordance with published magmatic ages of metagranite from western part of the Tseel Block ( $385 \pm 5$ Ma: Burenjargal et al. 2014; $372 \pm 3$ Ma: Cai et al. 2015) and of plagiogranite from the Tsogt Block (371 \pm 2 Ma: Bibikova et al. 1992).

Relatively low $\mathrm{Rb} / \mathrm{Sr}$ ratios, I-type major-element geochemistry, REE patterns with only weak negative Eu anomaly and radiogenic Hf isotopic signatures in the dated zircons all point to a rather primitive source of the protoliths to the orthogneisses. Still, their petrological character (metamorphosed granites-tonalites) and, in particular, conspicuous lack of more basic bodies effectively rules out a major role for mantle-derived melts. The studied rocks display high-K calc-alkaline chemistry 
Fig. 14 Major-element based plots serving for distinguishing prospective sources of granitic magmas. a - Binary plot $\mathrm{CaO} /\left(\mathrm{MgO}+\mathrm{FeO}_{\mathrm{t}}\right)$ vs. $\mathrm{Al}_{2} \mathrm{O}_{3} /(\mathrm{MgO}$ $+\mathrm{FeO}_{t}$ ) (in mol. \%) after Gerdes et al. (2002). Outlined are fields of experimental melts obtained by partial melting of metapelites, metagraywackes, metatonalites and metabasalts, as summarized by Gerdes et al. (2000). b - Binary plot $\mathrm{Al}_{2} \mathrm{O}_{3}+\mathrm{FeO}_{\mathrm{t}}+\mathrm{MgO}+\mathrm{TiO}_{2}$ vs. $\mathrm{Al}_{2} \mathrm{O}_{3} /$ $\left(\mathrm{FeO}_{\mathrm{t}}+\mathrm{MgO}+\mathrm{TiO}_{2}\right.$ ) (in wt. \%); outlined are domains that are occupied by experimental granitic melts derived by partial melting of metapelites, metagraywackes and amphibolites (Janoušek et al. 2010 and references therein).
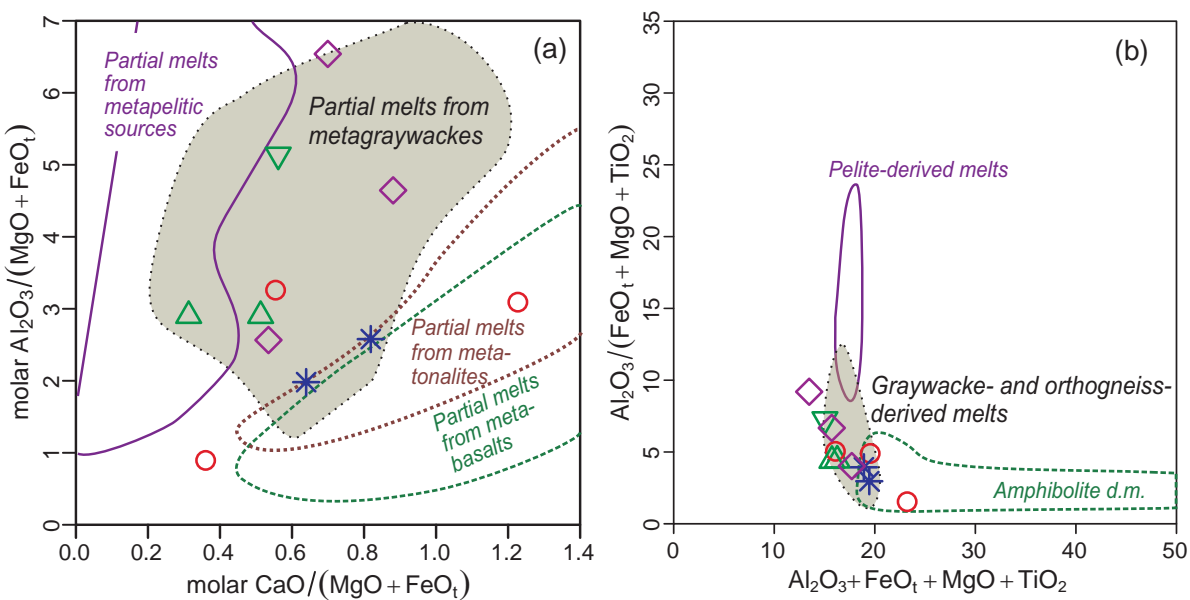

(Figs 8c-d) and the NMORB-normalized spider plots are characterized by enrichment in LILE and depletion in HFSE. Such compositions are typical of igneous rocks in magmatic arcs (e.g., Saunders et al. 1991; Pearce and Parkinson 1993; see also Figs 9, 11).

However, in case of absence/paucity of associated basic magmatic rocks, like ours, a caution should be exercised in interpretation of the geotectonic setting of granitoid rocks. Often, their arc-like signature is equivocal as it may be inherited from remelted metaigneous, arc-related rock suites (Arculus 1987), or immature sediments containing arc-derived detritus (Roberts and Clemens 1993; Janoušek et al. 2010).

Based on geochemistry, the studied orthogneisses can be most likely interpreted as a product of crustally derived, subaluminous melt crystallization. The relatively low $\mathrm{A} / \mathrm{CNK}$ values, $\mathrm{Rb} / \mathrm{Sr}$ (mostly below unity) and $\mathrm{Rb} / \mathrm{Ba}$ $(<0.45)$ as well as high $\mathrm{CaO} / \mathrm{Na}_{2} \mathrm{O}$ ratios $(0.15-0.84)$ are typical of magmas generated by partial melting of feldspar-rich psammitic or intermediate meta-igneous sources (Sylvester 1998; Jung and Pfänder 2007). Such a notion is also supported by the major-element plots of Gerdes et al. (2002) and Jung and Pfänder (2007) shown in Fig. 14.

The relatively radiogenic $\mathrm{Nd}$ in all studied metaigneous rocks (except the sample V039a) result in positive $\varepsilon_{N d}^{375}$ values of +2.5 to +5.5 (median $\sim+3.5$ ). These, in turn, translate to Neoproterozoic two-stage DepletedMantle Nd model ages (median $T_{D M}^{N d}$ is close to $0.8 \mathrm{Ga}$ - Fig. 12a).

Similar information is provided by the Hf isotopes in dated zircons. The positive $\varepsilon_{H f}^{t}$ values indicate rather juvenile parentage while the Hf mean crustal residence ages document a dominance of a (possibly recycled) Neoproterozoic crustal material in the source of the studied igneous rocks (Fig. 12b). The presence of material derived from pre-existing continental crust is further indicated by studied pre-Devonian zircon xenocrysts and inheritance. While ages of $c$. 430-440 Ma are not known from the
Tseel and adjacent terranes (Tab. 1), ages of c. 510-530 Ma correspond well with those of magmatic rocks in the Lake Zone (e. g. Dijkstra et al. 2006; Hrdličková et al. 2010; Rudnev et al. 2012, 2013; Jian et al. 2014). Moreover, the age of $\sim 740$ Ma resembles that known from coarse-grained orthogneiss of the Zamtyn Nuruu range, also in the Lake Zone (Demoux et al. 2009b; Hanžl et al. 2014) Therefore, the lower-middle crust underlying the studied region seems to have an affinity to the Neoproterozoic rocks of the Lake Zone.

\subsection{Age and likely genesis of the meta- rhyolites related to orthogneiss belts}

Only two grains from our meta-rhyolite sample yielded concordant ages of $c$. 380 and 403 Ma that could be interpreted as timing the igneous crystallization. These ages fit well with that of meta-rhyolites from the easternmost part of the Tsogt Block ( 397 Ma; Demoux et al. 2009a) and with the age of main thermal event in the Tseel Terrane (Kozakov et al. 2002; Burenjargal et al. 2014). The $\sim 530$ Ma population is interpreted as xenocrysts and their age corresponds to the inheritance from two other newly dated orthogneiss samples and meta-rhyolite from the eastern Tsogt Block (Demoux et al. 2009a). These authors interpreted meta-rhyolites as volcanic rocks of convergent continental margin with crustal residence age $<0.8$ $\mathrm{Ga}$, which is moreless in accord with our whole-rock $\mathrm{Nd}$ $\left(T_{D M}^{N d}=0.81\right.$ ad 0.84$)$ as well as zircon Hf isotopic data $\left(T_{D M}^{C}=0.70\right.$ and $\left.0.79 \mathrm{Ga}\right)$.

In fact, all the studied zircons from orthogneisses and meta-rhyolites yielded highly radiogenic Hf isotopic signatures, and thus also rather low $T_{D M}^{C}$ model ages. While in the SOB the Hf isotopic data point systematically to low $T_{D M}^{C}$ model ages of $0.74-0.87 \mathrm{Ga}$, the EOB orthogneisses contain a slightly more evolved component corresponding to $T_{D M}^{C}$ up to $1 \mathrm{Ga}$ (Fig. 12b). On the other hand, the lower limit of the rhyolite $T_{D M}^{C}$ model ages is $0.65 \mathrm{Ga}$, i.e. Neoproterozoic. 
Regardless these small differences, the highly positive whole-rock $\varepsilon_{N d}^{375}$ and zircon $\varepsilon_{H f}^{t}$ values as well as the presence of the negative $\mathrm{Nb}$ anomalies in the NMORBnormalized spiderplots of the rhyolites are consistent with a model of partial melting of a geochemically fairly primitive crust (immature metasediments or intermediate igneous rocks). The source was probably youthful, as shown by the profusion of the Early Cambrian ( $\sim 530 \mathrm{Ma})$ zircon grains. The most plausible options for the origin of the studied high-K calc-alkaline metaigneous rocks would be a partial melting of tonalitic rocks in the Cambrian magmatic arc (such as the Khantaishir Arc newly defined in the Lake Zone - Janoušek et al. 2015) or immature psammitic sediments (graywackes) derived therefrom (see also Roberts and Clemens 1993; Clemens 2012).

\subsection{Genesis of orthogneisses in the Tseel Terrane and implications for formation of Mongolian Altai continental crust}

The nature of the basement underneath the Tseel metamorphic rocks is a fundamental issue of proposed petrogenetic models of Mongolian and Chinese Altai granitoids (Jahn et al. 2000a; Cai et al. 2011) and geodynamic position of Mongolian Altai terranes (Wilhem et al. 2012) in the frame of the whole CAOB. However, the presence of such a pre-Devonian metamorphic basement with discordant Palaeozoic sedimentary cover was reported in the Mongolian and Gobi Altai only in former geological maps and papers, mainly by Russian authors (e.g. Rauzer et al. 1987) and designated as Riphean to Early Proterozoic based on geological mapping and lithological correlations.

This study describes rocks appearing, at the first glimpse, to be the best candidate for an old crystalline basement but geochronology and geochemistry clearly rule out such a possibility. Instead, the structural geology, geochemistry and isotopic dating of Mongolian Altai orthogneisses suggest that highly gneissified granitoids do not represent old basement imbricated with sediments but strongly deformed, gneissic Devonian granitoids. The source of such Devonian magmatism could be seen in melting of graywacke-dominated (Fig. 14) volcanosedimentary unit of Early Palaeozoic age with strong contribution of Late Proterozoic primitive rocks from the northerly Lake Zone as whole-rock Nd and zircons Hf isotopic compositions indicate.

This implies that the orthogneisses were originally emplaced as syn-orogenic granitic bodies during crustalscale vertical shortening event probably in form of sills parallel to the main sub-horizontal orogenic fabric. The abundance of orthogneiss sheets increased with the depth together with gabbros, migmatites and non-gneissic tonalites as exemplified by the current geology of the Tsogt
Block. In contrast, the upper and middle crust represented by Tugrug Fm. and Tseel metamorphic sequences are characterized by presence of isolated orthogneiss bodies, rare gabbros, rhyolites and undeformed granites of Devonian age (e.g. Burenjargal et al. 2014).

These observations indicate that the Devonian magmatism (both felsic and mafic) combined with melting of youthful graywacke-dominated complex and emplacement of syn-tectonic intrusions of granitoids probably completely transformed the lower crust of the Mongolian Altai. In contrast, the middle and upper crust preserves its original Early Palaeozoic lithological architecture being only marginally affected by Devonian magmatism and volcanism. Heterogeneous exhumation of deep magmatic and migmatitic edifice was also responsible for juxtaposition of lower crust with abundant Devonian granitoids to supracrustal meta-sedimentary rocks. Late Permian horizontal shortening welded deep crustal granitoids with supracrustal intrusions and their host rocks and transformed originally vertical crustal zoning to horizontal one. Such a complex crustal pattern has been also responsible for erroneous use of terrane approach in Mongolian and Chinese Altai, because the "terrane boundaries" coincide with Permian deformation zones, which bound different crustal levels of Mongolian Altai.

This study brings important arguments for the absence of an old crystalline basement in Mongolian Altai, which may modify substantially our current view on geodynamics of this critical region. An alternative model can be proposed suggesting formation of continental crust by syn-orogenic melting of youthful greywacke-dominated complex and emplacement of syn-tectonic intrusions of granitoids during orogen-scale vertical shortening. Such a process represents potentially a viable model for cratonization of accretionary systems worldwide.

Acknowledgements. This study was supported by GACR grant P210/12/2205 to K. Schulmann, PROCORE France/ Hong Kong Joint Research Scheme (to K. Schulmann and M. Sun) and 100 Talents Program of the Chinese Academy of Sciences (to Y.D. Jiang). This work is a contribution to IGCP \#592 Project "Continental construction in Central Asia". We acknowledge valuable comments of Keda Cai, an anonymous reviewer as well as the guest editor Wenjiao Xiao.

\section{References}

Amelin Y, Lee DC, Halliday AN, Pidgeon RT (1999) Nature of the Earth's earliest crust from hafnium isotopes in single detrital zircons. Nature 399: 252-255

ARCulus RJ (1987) The significance of source versus process in the tectonic controls of magma genesis. J Volcanol Geotherm Res 32: 1-12 
Badarch G, Cunningham WD, Windley BF (2002) A new terrane subdivision for Mongolia: implications for the Phanerozoic crustal growth of Central Asia. J Asian Earth Sci 21: 87-110

Bibikova EV, Kirnozova TI, Kozakov IK, Kotov AB, NeyMARK LA, GorkHOVSKIY BM, SHULESHKo IK (1992) U-Pb ages for polymetamorphic complexes on the southern flank of the Mongolian and Gobi Altai. Geotectonics 26: 166-172

Blichert-Toft J, Chauvel C, Albarède F (1997) Separation of $\mathrm{Hf}$ and Lu for high-precision isotope analysis of rock samples by magnetic sector-multiple collector ICP-MS. Contrib Mineral Petrol 127: 248-260

Boynton WV (1984) Cosmochemistry of the rare earth elements: meteorite studies. In: HENDERSON P (ed) Rare Earth Element Geochemistry. Elsevier, Amsterdam, pp 63-114

Broussolle A, Štípská P, Lehmann J, Schulmann K, Hacker BR, Holder R, Kylander-Clark ARC, Hanžl P, RaceK M, Hasalová P, Lexa O, HrdličKová K, Buriánek D (2015) P-T-t-D record of crustal-scale horizontal flow and magma-assisted doming in the SW Mongolian Altai. J Metamorph Geol 33: 359-383

Burenjargal U, Okamoto A, Meguro Y, Tsuchiya N (2012) An exhumation pressure-temperature path and fluid activities during metamorphism in the Tseel Terrane, SW Mongolia: constraints from aluminosilicate-bearing quartz veins and garnet zonings in metapelites. J Asian Earth Sci 54-55: 214-229

Burenjargal U, Okamoto A, Kuwatani T, Sakata S, Hirata T, Tsuchiya N (2014) Thermal evolution of the Tseel Terrane, SW Mongolia and its relation to granitoid intrusions in the Central Asian Orogenic Belt. J Metamorph Geol 32: 765-790

Burenjargal U, Okamoto A, Tsuchiya N, Uno M, Horie K, HoKADA T (2016) Contrasting geochemical signatures of Devonian and Permian granitoids from the Tseel Terrane, SW Mongolia. J Geosci 61: 51-66

Buriánek D, Janoušek V, Hanžl P, Jiang Y, Schulmann K, Lexa O, Altanbaatar B (2016) Petrogenesis of the Late Carboniferous Sagsai Pluton in the SE Mongolian Altai. J Geosci 61: 67-92

Cai K, Sun M, Yuan C, Zhao G, Xiao WJ, Long X, Wu F (2011) Prolonged magmatism, juvenile nature and tectonic evolution of the Chinese Altai, NW China: evidence from zircon U-Pb and Hf isotopic study of Paleozoic granitoids. J Asian Earth Sci 42: 949-968

Cai K, Sun M, Jahn BM, Xiao WJ, Yuan C, Long X, Chen $\mathrm{H}$, Tumurkhuu D (2015) A synthesis of zircon U-Pb ages and Hf isotopic compositions of granitoids from southwest Mongolia: implications for crustal nature and tectonic evolution of the Altai Superterrane. Lithos 232: $131-142$

Clemens JD (2012) Granitic magmatism, from source to emplacement: a personal view. Appl Earth Sci 121: 107-136
Cocks LRM, Torsvik TH (2007) Siberia, the wandering northern terrane, and its changing geography through the Palaeozoic. Earth Sci Rev 82: 29-74

Cunningham D (2005) Active intracontinental transpressional mountain building in the Mongolian Altai: defining a new class of orogen. Earth Planet Sci Lett 240: 436-444

Demoux A, Kröner A, Hegner E, Badarch G (2009a) Devonian arc-related magmatism in the Tseel Terrane of SW Mongolia: chronological and geochemical evidence. J Geol Soc, London 166: 459-471

Demoux A, Kröner A, Liu D, Badarch G (2009b) Precambrian crystalline basement in southern Mongolia as revealed by SHRIMP zircon dating. Int J Earth Sci 98: 1365-1380

Dergunov AB (2001) Tectonics, Magmatism, and Metallogeny of Mongolia. Routledge, London, pp 1-288

Dijkstra AH, Brouwer FM, Cunningham WD, Buchan C, Badarch G, Mason PRD (2006) Late Neoproterozoic proto-arc ocean crust in the Dariv Range, Western Mongolia: a supra-subduction zone end-member ophiolite. J Geol Soc, London 163: 363-373

Gerdes A, Wörner G, Henk A (2000) Post-collisional granite generation and HT-LP metamorphism by radiogenic heating: the Variscan South Bohemian Batholith. J Geol Soc, London 157: 577-587

Gerdes A, Montero P, Bea F, Fershtater G, Borodina N, Osipova T, Shardakova G (2002) Peraluminous granites frequently with mantle-like isotope compositions: the continental-type Murzinka and Dzhabyk batholiths of the eastern Urals. Int J Earth Sci (Geol Rundsch) 91: 3-19

Goldstein SL, O’Nions RK, Hamilton PJ (1984) A Sm-Nd isotopic study of atmospheric dusts and particulates from major river systems. Earth Planet Sci Lett 70: 221-236

Griffin WL, Belousova E, She SR, Pearson NJ, O’Reilly SY (2004) Archean crustal evolution in the northern Yilgarn Craton: U-Pb and Hf-isotope evidence from detrital zircons. Precambr Res 131: 231-282

Guy A, Schulmann K, Clauer N, Hasalová P, Seltmann R, Armstrong R, Lexa O, Benedicto A (2014a) Late Paleozoic-Mesozoic tectonic evolution of the Trans-Altai and South Gobi zones in southern Mongolia based on structural and geochronological data. Gondwana Res 25: 309-337

Guy A, Schulmann K, Munschy M, Miene JM, Edel JB, LEXA O, FAIRHEAD D (2014b) Geophysical constraints for terrane boundaries in southern Mongolia. J Geophys Res B Solid Earth 119: 7966-7991

Hanžl P, BuriáneK, D, Gerdes A, HrdličKová K, JanoušeK V, Schulmann K (2014) The Cambrian magmatic activity in the Zamtyn Nuruu range, Mongolian Altai. Geol Sudetica 4: 25

Hastie AR, Kerr AC, Pearce JA, Mitchell SF (2007) Classification of altered volcanic island arc rocks using immobile trace elements: development of the Th-Co discrimination diagram. J Petrol 48: 2341-2357 
Helo C, Hegner E, Kröner A, Badarch G, Tomurtogoo O, Windley BF, Dulski P (2006) Geochemical signature of Paleozoic accretionary complexes of the Central Asian Orogenic Belt in South Mongolia: constraints on arc environments and crustal growth. Chem Geol 227: 236-257

Hrdličková K, Bolormaa K, Buriánek D, Hanžl P, Gerdes A, JANOUŠEK V (2008) Petrology and age of metamorphosed rock in tectonic slices inside the Palaeozoic sediments of the eastern Mongolian Altay, SW Mongolia. J Geosci 53: 139-165

HrdličKová K, Gerdes A, Gilíková H, Dash B, HanžL P (2010) Burd Gol granite Massif as a typical product of the Late Cambrian post-orogenic magmatism in the SE part of the Lake Zone, Gobi Altay, SW Mongolia. J Geosci 55: 369-386

Izokn AE, Vishnevskit AV, Polyakov GV, Shelepaev RA (2011) Age of picrite and picrodolerite magmatism in western Mongolia. Russ Geol and Geophys 52: 7-23

JAHN BM (2004) The Central Asian Orogenic Belt and growth of the continental crust in the Phanerozoic. In: Malpas J, Fletcher A, Ali JR, Aitchison JC (eds) Aspects of the Tectonic Evolution of China. Geological Society London Special Publications 226: pp 73-100

JAHN BM, Wu FY, CHEN B (2000a) Granitoids of the Central Asian Orogenic Belt and continental growth in the Phanerozoic. Tr Roy Soc Edinb, Earth Sci 91: 181-193

JAHN BM, Wu FY, CHeN B (2000b) Massive granitoid generation in Central Asia: $\mathrm{Nd}$ isotope evidence and implications for continental growth in the Phanerozoic. Episodes 23: 82-92

JACOBSEn SOB, Wasserburg GJ (1980) Sm-Nd isotopic evolution of chondrites. Earth Planet Sci Lett 50: 139-155

JANOUŠEK V, FARROW CM, ERBAN V (2006) Interpretation of whole-rock geochemical data in igneous geochemistry: introducing Geochemical Data Toolkit (GCDkit). J Petrol 47: 1255-1259

Janoušek V, Konopásek J, Ulrich S, ERban V, TajČmanová L, JEŘÁBEK P (2010) Geochemical character and petrogenesis of Pan-African Amspoort suite of the Boundary Igneous Complex in the Kaoko Belt (NW Namibia). Gondwana Res 18: 688-707

JanOUŠEK V, JiAng Y, BuRiánek D, Schulmann K, HanžL P, Altanbaatar B, Ganchuluun T, Lexa O, Erban V (2015) The Cambrian Khantaishir Arc - a conspicuous and geotectonically important structure in the Lake Zone of the Mongolian Altai (Central Asian Orogenic Belt). In: Lexa O, Hasalová P, JeřáBeK P (eds) CETEG 2015 $-13^{\text {th }}$ Meeting of the Central European Tectonic Groups and $20^{\text {th }}$ Meeting of the Czech Tectonic Studies Group (ČTS), Kadaň, 22-25 April, 2015, Abstract Volume. Czech Geological Survey, Prague, pp 32

Jensen LS (1976) A New Cation Plot for Classifying Subalkalic Volcanic Rocks. Ontario Geological Survey Miscellaneous Papers 66, pp 1-22
Jian P, KRÖner A, Jahn BM, Windley BF, Shi Y, Zhang W, Zhang F, Miao L, Tomurhuu D, Liu D (2014) Zircon dating of Neoproterozoic and Cambrian ophiolites in West Mongolia and implications for the timing of orogenic processes in the central part of the Central Asian Orogenic Belt. Earth Sci Rev 133: 62-93

Jiang Y, Sun M, Zhao G, Yuan C, Xiao W, Xia X, Long X, Wu F (2011) Precambrian detrital zircons in the Early Paleozoic Chinese Altai: their provenance and implications for the crustal growth of Central Asia. Precambr Res 189: 140-154

Jiang Y, Sun M, Kröner A, Tumurkhuu D, Long X, ZhaO GC, YuAn C, XiaO WJ (2012) The high-grade Tseel Terrane in SW Mongolia: an Early Paleozoic arc system or a Precambrian sliver? Lithos 142-143: 95-115

JiAng YD, ŠTíPSKÁ P, Sun M, Schulmann K, Zhang J, Wu QH, Long XP, Yuan C, Racek M, Zhao GC, Xiao WJ (2015) Juxtaposition of Barrovian and migmatite domains in the Chinese Altai: a result of crustal thickening followed by doming of partially molten lower crust. J Metamorph Geol 33: 45-70

Jung S, Pfänder JA (2007) Source composition and melting temperatures of orogenic granitoids: constraints from $\mathrm{CaO} / \mathrm{Na}_{2} \mathrm{O}, \mathrm{Al}_{2} \mathrm{O}_{3} / \mathrm{TiO}_{2}$ and accessory mineral saturation thermometry. Eur J Mineral 19: 859-870

Kovalenko V, Yarmolyuk V, Kovach V, Kotov A, KozaKOV I, SAL'NIKOVA E, LARIN A (2004) Isotope provinces, mechanisms of generation and sources of the continental crust in the Central Asian mobile belt: geological and isotopic evidence. J Asian Earth Sci 23: 605-627

Kozakov IK, Glebovitsky V, Bibikova EV, Azimov PY, KiRnOzOva T (2002) Hercynian granulites of Mongolian and Gobian Altai: geodynamic setting and formation conditions. Dokl Earth Sci 386: 781-785

Kozakov IK, Kovach VP, Bibikova EV, Kirnozova TI, Zagornaya NY, Plotkina YV, Podkovyrov VN (2007) Age and sources of granitoids in the junction zone of the Caledonides and Hercynides in southwestern Mongolia: geodynamic implications. Petrology 15: 126-150

Kozakov IK, Didenko AN, Azimov PY, Kirnozova TI, Sal'nikova EB, Anisimova IV, Erdenejargal C (2011) Geodynamic settings and formation conditions of crystalline complexes in the South Altai and South Gobi metamorphic belts. Geotectonics 45: 174-194

Kröner A, Windley B, Badarch G, Tomurtogoo O, Hegner E, Jahn BM, Gruschka S, Khain E, Demoux A, Wingate MTD (2007) Accretionary growth and crust formation in the Central Asian Orogenic Belt and comparison with the Arabian-Nubian Shield. In: HATCHER JR RD, CARLson MP, McBride JH, Martínez Catalán JR (eds) 4-D Framework of Continental Crust. Geological Society of America Memoirs 200. 181-209

Kröner A, Lehmann J, Schulmann K, Demoux A, Lexa O, Tomurhuu D, Štípská P, Liu D, Wingate MTD (2010) 
Lithostratigraphic and geochronological constraints on the evolution of the Central Asian Orogenic Belt in SW Mongolia: Early Paleozoic rifting followed by Late Paleozoic accretion. Amer J Sci 310: 523-574

KRUK N (2015) Continental crust of Gorny Altai: stages of formation and evolution - indicative role of granitoids. Russ Geol Geophys 56: 1097-1113

LAMB MA, BADARCH G (2001) Paleozoic sedimentary basins and volcanic arc systems of southern Mongolia: new geochemical and petrographic constraints. In: HENDRIX SM, Davis AG (eds) Paleozoic and Mesozoic Tectonic Evolution of Central and Eastern Asia: From Continental Assembly to Intracontinental Deformation. Geological Society of America Memoirs 1094: pp 117-149

Lehmann J, Schulmann K, Lexa O, Corsini M, Kröner A, ŠTípská P, TomurhuU D, OtGonbator D (2010) Structural constraints on the evolution of the Central Asian Orogenic Belt in SW Mongolia. Amer J Sci 310: 575-628

Li XH, Long WG, Li QL, Liu Y, Zheng YF, YANG YH, Chamberlain KR, Wan DF, Guo CH, Wang XC, Tao H (2010) Penglai zircon megacrysts: a potential new working reference material for microbeam determination of $\mathrm{Hf}-\mathrm{O}$ isotopes and $\mathrm{U}-\mathrm{Pb}$ age. Geost Geoanal Res 34: 117-134

Liew TC, Hofmann AW (1988) Precambrian crustal components, plutonic associations, plate environment of the Hercynian Fold Belt of Central Europe: indications from a Nd and Sr isotopic study. Contrib Mineral Petrol 98: $129-138$

LiU W, LiU XJ, XIAo WJ (2012) Massive granitoid production without massive continental-crust growth in the Chinese Altay: insight into the source rock of granitoids using integrated zircon $\mathrm{U}-\mathrm{Pb}$ age, $\mathrm{Hf}-\mathrm{Nd}-\mathrm{Sr}$ isotopes and geochemistry. Amer J Sci 312: 629-684

Liu Y, Hu Z, Gao S, Günther D, Xu J, Gao C, Chen H (2008) In situ analysis of major and trace elements of anhydrous minerals by LA-ICP-MS without applying an internal standard. Chem Geol 257, 34-43

Long X, Yuan C, Sun M, Xiao W, Wang Y, Cai K, Jiang Y (2012) Geochemistry and Nd isotopic composition of the Early Paleozoic flysch sequence in the Chinese Altai, Central Asia: evidence for a northward-derived mafic source and insight into Nd model ages in accretionary orogen. Gondwana Res 22: 554-566

LuDwIG KR (2003) Isoplot/Ex version 3.00. A Geochronological Toolkit for Microsoft Excel, User's Manual. Berkeley Geochronology Center Special Publications 4, pp 1-70

Lugmair GW, Marti K (1978) Lunar initial ${ }^{143} \mathrm{Nd} /{ }^{144} \mathrm{Nd}$ : differential evolution line of the lunar crust and mantle. Earth Planet Sci Lett 39: 349-357

Machado N, Simonetti A (2001) U-Pb dating and Hf isotopic composition of zircons by laser ablation-MC-ICPMS. In: SyLVESTER P (ed) Laser-Ablation-ICPMS in the Earth Sciences: Principles and Applications. Mineralogical Association of Canada Short Courses 29, pp 121-146
Markova NG (1975) Stratigraphy of the Early and Middle Paleozoic of Western Mongolia. Transactions of Joint Soviet-Mongolian Scientific Research Geological Expedition 12. Nauka Press, Moscow, pp 1-119 (in Russian)

Mielke P, WinkLer HGF (1979) Eine bessere Berechnung der Mesonorm fur granitische Gesteine. Neu Jb Mineral, Mh 1979: 471-480

Míková J, Denková P (2007) Modified chromatographic separation scheme for $\mathrm{Sr}$ and $\mathrm{Nd}$ isotope analysis in geological silicate samples. J Geosci 52: 221-226

Mossakovisky A, Ruzhentsev S, Samygin S, Kheraskova T (1994) Central Asian Fold Belt: geodynamic evolution and formation history. Geotectonics 27: 445-474

Pearce JA, Parkinson IJ (1993) Trace element models of mantle melting: application to volcanic arc petrogenesis. In: Prichard HM, Alabaster T, Harris NBW, Neary CR (eds) Magmatic Processes and Plate Tectonics. Geological Society of London Special Publications 76: pp 373-403

Pearce JA, Harris NBW, Tindle AG (1984) Trace element discrimination diagrams for the tectonic interpretation of granitic rocks. J Petrol 25: 956-983

Peccerillo A, Taylor SR (1976) Geochemistry of Eocene calc-alkaline volcanic rocks from the Kastamonu area, Northern Turkey. Contrib Mineral Petrol 58: 63-81

Pin C, Zalduegui JFS (1997) Sequential separation of light rare-earth elements, thorium and uranium by miniaturized extraction chromatography: application to isotopic analyses of silicate rocks. Anal Chim Acta 339: 79-89

Pin C, Briot D, Bassin C, Poitrasson F (1994) Concomitant separation of strontium and samarium-neodymium for isotopic analysis in silicate samples, based on specific extraction chromatography. Anal Chim Acta 298: 209-217

Rauzer AA, Zhanchiv DI, Golyakov VI, YKhina IF, IVANOV IG, Tsukernik AB, Afonin VV, SMirnov IG, BYKhover VI, Kravtsev AV, BaAtarkhuyag A, Skoryukin MI, Khodikov IV, Mantsev NV, Okaemov SV, Mischin VA, Enkhsajkhan T (1987) Report on Results of Geological Survey on the scale of 1: 200,000, Performed in Southeast Part of the Mongolian Altay, Mongolian National Republic in 19831986. Tekhnoexport, Moscow, pp 1-769 (in Russian)

RoBERTS MP, ClEMENS JD (1993) Origin of high-potassium, calc-alkaline, I-type granitoids. Geology 21: 825-828

Rojas-Agramonte Y, Kröner A, Demoux A, Xia X, Wang W, Donskaya T, Liu D, Sun M (2011) Detrital and xenocrystic zircon ages from Neoproterozoic to Palaeozoic arc terranes of Mongolia: significance for the origin of crustal fragments in the Central Asian Orogenic Belt. Gondwana Res 19: 751-763

Rudnev SN, Izokh AE, Kovach VP, Shelepaev RA, Terent'eva LB (2009) Age, composition, sources, and geodynamic environments of the origin of granitoids in the northern part of the Ozernaya Zone, western Mongolia: growth mechanisms of the Paleozoic continental crust. Petrology 17: 439-475 
Rudnev SN, Izokh AE, Borisenko AS, Shelepaev RA, Orinashi Y, Lobanov KV, Vishnevsky AV (2012) Early Paleozoic magmatism in the Bumbat-Hairhan area of the Lake Zone in western Mongolia (geological, petrochemical and geochronological data). Russ Geol Geophys 53: 425-441

Rudnev SN, Kovach VP, Ponomarchuk VA (2013) VendianEarly Cambrian island-arc plagiogranitoid magmatism in the Altai-Sayan folded area and in the Lake Zone of western Mongolia (geochronological, geochemical, and isotope data). Geol Geophys 54: 1272-1287

Sal'nikova EB, Kozakov IK, Kotov AB, Kröner A, Todt W, Bibikova EV, Nutman A, Yakovleva SZ, Kovach VP (2001) Age of Palaeozoic granites and metamorphism in the Tuvino-Mongolian Massif of the Central Asian Mobile Belt: loss of a Precambrian microcontinent. Precambr Res 110: 143-164

Saunders AD, Norry MJ, Tarney J (1991) Fluid influence on the trace element compositions of subduction zone magmas. In: Tarney J, Pickering KT, Knipe RJ, Dewey JF (eds) The Behaviour and Influence of Fluids in Subduction Zones. The Royal Society, London, pp 151-166

Schandl ES, Gorton MP (2002) Application of high field strength elements to discriminate tectonic settings in VMS environments. Econ Geol 97: 629-642

Shand SJ (1943) Eruptive Rocks. Their Genesis, Composition, Classification, and Their Relation to Ore-Deposits with a Chapter on Meteorite. John Wiley \& Sons, New York, pp 1-444

SöDerlund U, Patchett PJ, Vervoort JD, Isachsen CE (2004) The ${ }^{176} \mathrm{Lu}$ decay constant determined by Lu-Hf and $\mathrm{U}-\mathrm{Pb}$ isotope systematics of Precambrian mafic intrusions. Earth Planet Sci Lett 219: 311-324

Steiger RH, Jäger E (1977) Subcommission on Geochronology; convention on the use of decay constants in geoand cosmochronology. Earth Planet Sci Lett 36: 359-362

Streckeisen A, Le Maitre RW (1979) A chemical approximation to the modal QAPF classification of the igneous rocks. Neu Jb Mineral, Abh 136: 169-206

Sun M, Yuan C, Xiao W, Long X, XIa X, Zhao G, Lin S, Wu F, KRÖNER A (2008) Zircon U-Pb and Hf isotopic study of gneissic rocks from the Chinese Altai: progressive accretionary history in the early to middle Palaeozoic. Chem Geol 247: 352-383

Sun M, Long XP, CaI KD, Jiang YD, Wang BY, Yuan C, Zhао GC, Xıаo WJ, Wu FY (2009) Early Paleozoic ridge subduction in the Chinese Altai: insight from the abrupt change in zircon Hf isotopic compositions. Science in China, Series D: Earth Sciences 52: 1345-1358

Sun SS, McDonough WF (1989) Chemical and isotopic systematics of oceanic basalts: implications for mantle composition and processes. In: SAUnders AD, Norry M (eds) Magmatism in the Ocean Basins. Geological Society of London Special Publications 42: pp 313-345
Sylvester PJ (1998) Post-collisional strongly peraluminous granites. Lithos 45: 29-44

Şengör A, Natal' 'n B, Burtman V (1993) Evolution of the Altaid tectonic collage and Palaeozoic crustal growth in Eurasia. Nature 364: 299-307

Tanaka T, Togashi S, Kamioka H, Amakawa H, Kagami H, Hamamoto T, Yuhara M, Orihashi Y, Yoneda S, Shimizu H, Kunimaru T, Takahashi K, Yanagi T, Nakano T, Fujimaki H, Shinjo R, Asahara Y, Tanimizu M, Dragusanu C (2000) JNdi-1: a neodymium isotopic reference in consistency with LaJolla neodymium. Chem Geol 168: 279-281

Wang T, JAHN BM, Kovach VP, Tong Y, Hong DW, HaN BF (2009) Nd-Sr isotopic mapping of the Chinese Altai and implications for continental growth in the Central Asian Orogenic Belt. Lithos 110: 359-372

Wasserburg GJ, Jacobsen SOB, DePaolo DJ, McCullосн MT, Wen T (1981) Precise determination of Sm/ $\mathrm{Nd}$ ratios, Sm and Nd isotopic abundances in standard solutions. Geochim Cosmochim Acta 45: 2311-2324

WhitNey LD, Evans WB (2010) Abbreviations for names of rock-forming minerals. Amer Miner 95: 185-187

Wilhem C, Windley BF, Stampfl GM (2012) The Altaids of Central Asia: a tectonic and evolutionary innovative review. Earth Sci Rev 113: 303-341

WinCHESTER JA, FLOYD PA (1977) Geochemical discrimination of different magma series and their differentiation products using immobile elements. Chem Geol 20: 325-343

Windley BF, Alexeiev D, Xiao WJ, Kröner A, Badarch G (2007) Tectonic models for accretion of the Central Asian Orogenic Belt. J Geol Soc, London 164: 31-47

Wu FY, YANG YH, XIE LW, YANG JH, Xu P (2006) Hf isotopic compositions of the standard zircons and baddeleyites used in U-Pb geochronology. Chem Geol 234: 105-126

Xia X, Sun M, Geng H, Sun Y, Wang Y, Zhao G (2011) Quasi-simultaneous determination of $\mathrm{U}-\mathrm{Pb}$ and $\mathrm{Hf}$ isotope compositions of zircon by excimer laser-ablation multiplecollector ICPMS. J Anal Atom Spectrom 26: 1868-1871

Xiao WJ, Windley B, Han C, Yuan C, Sun M, Li J, Sun S (2009) End Permian to mid-Triassic termination of the southern Central Asian Orogenic Belt. Int J Earth Sci 98: 1189-1217

Yarmolyuk VV, Kovalenko VI, Kozlovsky AM, Kovach VP, Sal'nikova EB, Kovalenko DV, Kotov AB, Kudryashova EA, Lebedev VI, Eenzhin G (2008) Crustforming- processes in the Hercynides of the Central Asian Foldbelt. Petrology 16: 679-709

Yuan C, Sun M, Xiao W, Li X, Chen H, Lin S, Xia X, Long $X$ (2007) Accretionary orogenesis of the Chinese Altai: insights from Paleozoic granitoids. Chem Geol 242: 22-39

Zhang J, Sun M, Schulmann K, Zhao G, Wu Q, Jiang Y, GuY A, WANG Y (2015) Distinct deformational history of two contrasting tectonic domains in the Chinese Altai: their significance in understanding accretionary orogenic process. J Struct Geol 73: 64-82 